\title{
Current Perspectives on the Diagnosis and Management of Healthcare-Associated Ventriculitis and Meningitis
}

\author{
Marios Karvouniaris $\mathbb{D D}^{1}$, Alexandros Brotis $\mathbb{D}^{2}$, Konstantinos Tsiakos $\mathbb{D}^{3}$, Eleni Palli $\mathbb{D}^{4}$, \\ Despoina Koulenti ${ }^{5,6}$
}

'Intensive Care Unit, AHEPA University Hospital, Thessaloniki, Greece; ${ }^{2}$ Neurosurgery Department, University Hospital of Larissa, Larissa, Greece; ${ }^{3}$ Third Department of Internal Medicine, "Sotiria" Hospital, Athens, Greece; ${ }^{4}$ Intensive Care Unit, University Hospital of Larissa, Larissa, Greece; ${ }^{5}$ Second Critical Care Department, Attikon University Hospital, Athens, Greece; ${ }^{6}$ Q Centre for Clinical Research, Faculty of Medicine, The University of Queensland, Brisbane, Queensland, Australia

Correspondence: Marios Karvouniaris, ACHEPA University Hospital, S.Kiriakidi I, Thessaloniki, 54636, Greece, Tel +3023 I3303645, Fax+302313303096, Email karvmarevg@hotmail.com

\begin{abstract}
Ventriculitis or post-neurosurgical meningitis or healthcare-associated ventriculitis and meningitis (VM) is a severe infection that complicates central nervous system operations or is related to the use of neurosurgical devices or drainage catheters. It can further deteriorate patients who have already presented significant neurologic injury and is associated with high morbidity, mortality, and poor functional outcome. VM can be difficult to distinguish from aseptic meningitis, inflammation that follows hemorrhagic strokes and neurosurgical operations. The associated microorganisms can be either skin flora or nosocomial pathogens, most commonly, Gram-negative bacteria. Classical microbiology can fail to isolate the culprit pathogen. Novel cerebrospinal fluid (CSF) biomarkers and molecular microbiology can fill the diagnostic gap and expedite pathogen identification and treatment. The pathogens may demonstrate significant resistant patterns and their antibiotic treatment can be difficult, as many important drug classes, including the beta-lactams and the glycopeptides, hardly penetrate to the CSF, and do not achieve therapeutic levels at the site of the infection. Treatment modifications, such as higher daily dose and prolonged or continuous administration, might increase antibiotic levels in the site of infection and facilitate pathogens clearance. However, in the case of therapeutic failure or infection due to difficultto-treat bacteria, the direct antibiotic instillation into the CSF, in addition to the intravenous antibiotic delivery, may help in the resolution of infection. However, intraventricular antibiotic therapy may result in aseptic meningitis and seizures, concerning the administration of aminoglycosides, polymyxins, and vancomycin. Meanwhile, bacteria form biofilms on the catheter or the device that should routinely be removed. Novel neurosurgical treatment modalities comprise endoscopic evacuation of debris and irrigation of the ventricles. VM prevention includes perioperative antibiotics, antimicrobial impregnated catheters, and the implementation of standardized protocols, regarding catheter insertion and manipulation.
\end{abstract}

Keywords: ventriculitis, cerebrospinal fluid, external ventricular drain, molecular diagnostics, antibiotic penetration, intraventricular treatment

\section{Introduction}

Ventriculitis or post-neurosurgical meningitis or healthcare-associated ventriculitis and meningitis (VM) is a severe disease of diverse etiology, following central nervous system (CNS) operation or trauma or the insertion of central nervous system (CNS) device. ${ }^{1,2}$ In the post-neurosurgical setting, this infection presents at a rate of less than $1 \%$ to as high as $8.6 \%{ }^{3,4}$ Rates vary between studies using different definitions of meningitis. Moreover, diverse implantable devices are used for the diagnosis and treatment of numerous neurological disorders. These devices might be inserted temporarily, like external ventricular (EVD) and lumbar drains for measuring the intracranial pressure and cerebrospinal fluid (CSF) diversion. The reported VM incidence varies widely between $2 \%$ and $22 \%$. In addition, the pooled incidence rate of EVD-associated ventriculitis was estimated at 11.4 per 1000 catheter-days (95\% CI, 9.3-13.5) and in a recent 
study, the mean rate was 3.96/1000 catheter-days. ${ }^{5-7}$ On the other hand, ventriculoperitoneal (VP) and ventriculoatrial shunts to the peritoneal cavity and the right atrium, respectively, provide more permanent CSF diversion alternatives. The VP shunts are used more often, having an infection rate of 11.7\% (range 4.1-20.5\%). ${ }^{8}$ Finally, several cranial or spinal neurostimulators and baclofen infusion pumps are implanted to manage various conditions, from Parkinson's disease and obsessive-compulsive disorders to spasticity and morbid obesity. However, the latter interventions carry only a small (much less than $1 \%$ ) risk for a device-associated $\mathrm{VM}^{9} .^{-11}$

Ventriculitis is associated with high mortality in the range of $15 \%$ to $23 \%$ which can be improved with adequate initial treatment. ${ }^{12,13}$ EVD infection can double the length of catheterization, the intensive care unit (ICU) stay, and the total health-care costs. ${ }^{14}$

Another issue of growing importance is the shift in microbiology during the last decade towards Gram-negative (GN) infection, notably with Acinetobacter baumannii, becoming more common. ${ }^{1,15}$ This emergence of difficult-to-treatresistant GN pathogens ${ }^{16}$ can lead to inappropriate, discordant antibiotic treatment which may adversely affect the outcome. $^{17}$

The literature search shows a lack of standardized diagnostic and treatment protocols as neurosurgical centers deal with variable pathologies, local flora, and infection control policies. Therefore, they can hardly perform high-quality, multi-center, controlled studies, and the available recommendations are based on weak evidence and heterogeneous reports. ${ }^{1,15}$

In this review, we aim to identify current perspectives and discuss controversies and challenges on the diagnosis and management of VM.

\section{Risk Factors}

VM following neurosurgical operations seemed to be associated with the extent of dural opening during the procedure. ${ }^{12}$ Craniotomy predisposed the infection more than shunt insertion while spinal fusion has been even less associated with VM. ${ }^{12}$ Despite its value, EVD is a foreign body with an inherent risk of infection. The insertion technique and venue, the catheterization duration, the presence of blood in the CSF, the presence of CSF leak, and regular catheter sampling and manipulation, including EVD exchange, have been all associated with increased risk for VM. ${ }^{18,19}$ Of interest, the use of bilateral catheters might elevate the risk of $\mathrm{VM}^{20}{ }^{20}$ The average time from the operation to the diagnosis of VM was 10.3 days analogous to the EVD-related infection, which peaked at about 10 days post-insertion. ${ }^{12,19}$ Regarding VP shunts, device revision due to prior shunt infection or malfunction, and post-neurosurgical leak, increase the infection risk the most. ${ }^{21,22}$

\section{Pathogenesis-Microbiology}

The microorganisms responsible for VM, which reside in the patient's skin flora (Staphylococcus spp., Cutibacterium acnes) or the hospital environment (various pathogens including GN bacilli), gain direct access to the subarachnoid space and/or the cerebral ventricles following craniotomy or the external diversion of the CSF. Overall, colonization precedes infection $;^{23}$ the catheter is colonized directly during its entry from a failure of the sterile technique or intraluminally following CSF sampling or by the microorganisms extraluminally migrating down the drain tract. Rarely, the drain can be hematogenously colonized. ${ }^{22}$

Bacteria frequently form biofilms, colonies growing within a polysaccharide matrix upon the device surface, protecting the microorganisms from the host's immune system and the administered antibiotics. ${ }^{22}$ Regarding EVDs, most drains develop biofilm after day 7 post-insertion. ${ }^{24}$ Apart from GP bacteria, GN pathogens, particularly A. baumannii, are linked to biofilm-associated nosocomial infections. ${ }^{25,26}$ In the early stages of the infection and up to 6 weeks, the biofilm is usually "immature" and amenable to rigorous surgical debridement and antimicrobial therapy, and possibly device removal can be avoided. However, in later stages, the "mature" biofilm requires device removal and prolonged antibiotic administration. ${ }^{22}$

The relative frequency of the causative agents varies between different countries or different hospitals. ${ }^{1}$ In a recent multicenter study, both GP and GN pathogens were equally isolated. ${ }^{27}$ However, there has been a steady increase in the prevalence of DTR-GN isolates in many centers around the globe, including multidrug-resistant Pseudomonas aeruginosa, and the carbapenemase-resistant A. baumannii and Klebsiella pneumoniae. ${ }^{28-30}$ It should be highlighted that, 
although GN-VM patients were sicker compared to GP-VM-affected individuals, there were no consistent differences regarding outcomes. ${ }^{31,32}$

Although bacteria are the predominant CSF isolates, Candida species can rarely cause VM, which is a late occurrence, associated with the use of CSF-diversion devices, and follows prolonged antibiotic treatments for nosocomial infections. Of note, the antecedent infection is a previous bacterial VM, while there is a paucity of data regarding any characteristics that differentiate this entity from the bacterial one. ${ }^{33,34}$ The mortality can be as high as $27 \%{ }^{34}$

\section{Diagnosis \\ Non-Microbiological Diagnosis}

The clinical presentation of VM varies according to the patient's age, primary neurological disease, the underlying pathogen, and the critical care status of the individual. ${ }^{6,35,36}$

Patients with VM may present fever $>38.0^{\circ} \mathrm{C}$, meningeal irritation, and cranial nerve palsies. ${ }^{37}$ Although fever can be the primary sign of $\mathrm{VM}$, it is non-specific. ${ }^{38,39}$ On the other hand, the clinical presentation of shunt infections is more obscure and, usually, includes headache, malaise, and altered consciousness. Hydrocephalus might occur as well due to shunt malfunction. ${ }^{40}$ In addition, the drainage tubing course is frequently hard, red, and tender. Depending on the location of the distal end, an infected shunt could also manifest as peritonitis, pleuritis, bacteremia, and endocarditis or immune complex glomerulonephritis. ${ }^{41,42}$

Serum markers, notably procalcitonin and not C-reactive protein, might point to the presence of VM in EVD-treated trauma patients after excluding other infection sites. ${ }^{43}$ Regarding CSF, its composition in VM patients is altered, exhibiting increased leucocyte (WBC) and protein values, with decreased glucose levels. ${ }^{37}$ Admittedly, the differentiation of VM from postoperative aseptic meningitis (AM) is challenging due to the intraoperative CSF contamination with blood, including leucocytes, and the inflammatory reaction to heme metabolism byproducts. ${ }^{44,45}$ Nowadays, it is common to adjust the CSF cell count for red blood cells (RBC), using the cell index (CI), a ratio of the WBC to RBC in the CSF divided by the ratio of WBC to RBC in the blood. ${ }^{41}$ It assumes that the CSF WBC to RBC ratio is roughly proportional to peripheral blood in patients with intracranial hemorrhage. Any deviation to this general rule, which may occur during infection can impact the CI. The diagnostic accuracy of CI differed according to the population under study. ${ }^{45,46}$ Indeed, Liew et al studied the diagnostic value of the CI in EVD-treated, predominantly intracerebral hemorrhage patients. The peak CI of VM patients, sampled within 72 hours preceding the diagnosis, significantly differed from the highest value, at any given day, of non-VM individuals and exhibited a cut-off value of 10.4 that was associated with sensitivity and specificity rates as high as $80.5 \%$ and $70.5 \%$, respectively. ${ }^{46}$ Montes et al studied a patient cohort of intracranial hemorrhage only and reported that $\mathrm{CI}$ had the best diagnostic accuracy among various indices, with a corresponding area under the receiver operating curve (AUC) of 0.825, outperforming the corrected CSF WBC count $(0.770)$ and uncorrected CSF WBC count (0.652). ${ }^{45}$

Researchers have targeted several CSF biomarkers with interesting results. CSF lactate can be valuable for differentiating bacterial from aseptic meningitis. ${ }^{47}$ A meta-analysis of 404 post-neurosurgical patients, using a lactate cut-off of $4.41 \pm 0.85 \mathrm{mmol} / \mathrm{L}$ demonstrated a pooled sensitivity and specificity as high as $92 \%$ and $88 \%$, respectively. ${ }^{47}$ Notwithstanding, CSF lactate may also increase in several other intracranial pathologies like ischemia, subarachnoid vasospasm, seizures, and trauma, while it might decrease following antimicrobial administration. ${ }^{39,47,48}$

In a study of 239 post-neurosurgical patients, Abudeev et al focused on presepsin, a biomarker produced by the microglial cells and unaffected by the presence of blood in the CSF. The optimal threshold concentration for diagnosing culture-positive VM was $1257.5 \mathrm{pg} / \mathrm{mL}$ with moderate diagnostic accuracy (AUC 0.725). ${ }^{49}$ However, when combined with CSF lactate, the diagnostic efficiency was boosted (AUC, 0.856 with a sensitivity of $82.8 \%$ and specificity of $73.5 \%$ ). ${ }^{50}$

Lenski et al retrospectively studied 40 EVD-treated traumatic brain injury patients for markers of inflammation. CSF interleukin-6, at a cutoff of $4064 \mathrm{pg} / \mathrm{mL}$, detected VM better than CSF's WBC and protein, with a sensitivity and specificity of $100 \%$ and $92.3 \%$ for early diagnosis. ${ }^{51}$ The same group investigated 63 individuals with subarachnoid hemorrhage (SAH) for the potential of CSF IL-6 to discriminate VM from vasospasm and sole SAH. The respective AUCs were 0.757 and 1.0 and a cutoff value of more than $3081 \mathrm{pg} / \mathrm{mL}$ probably presented VM. ${ }^{52}$ This population was 
further examined for increased inflammatory markers (neutrophil percentage, total cell count, glucose, protein in the CSF, and the CSF to blood glucose ratio) to discriminate infection from AM. The neutrophil percentage AUC prevailed with a value of 0.900 and the total cell count followed with $0.841 .^{53}$

Regarding the combination of CSF diagnostic markers, Zhang et al studied 112 neurosurgical patients with suspected CNS infection. The AUC for differentiating VM from aseptic inflammation was $0.936(0.895-0.977)$ for lactate, $0.803(0.724-0.883)$ for procalcitonin, $0.860(0.797-0.929)$ for interleukin-10, and $0.771(0.683-0.860)$ for interleukin-8. However, the composite AUC for all the parameters was $0.954(0.922-0.989) .{ }^{54}$ The AUC of IL-1 $\beta$, another cytokine, for detecting VP-shunt associated VM at a cutoff value of $4 \mathrm{pg} / \mathrm{mL}$ was $0.927 .{ }^{55}$ Liu et al investigated 32 post-neurosurgical feverish patients for the CSF cytokine and procalcitonin kinetics on days -4 , $-2,0,2$, and 4 days concerning the fever onset. The proinflammatory cytokines assessed were tumor necrosis factor$\alpha$, interleukin-1 $\beta$, interleukin-6, and interleukin- 8 , which were significantly increased, starting 4 days before fever commencement, in the bacterial VM group compared to the AM group patients who in turn had higher values than their non-meningitis counterparts. Contrary to that, procalcitonin levels elevated late, on day 4 post-fever onset. ${ }^{56}$

The potential of CSF cytokine profile for diagnosing VM was examined in a recent study with a two-step process: in the first step, patients with neuroinflammation, in general, were identified via the biomarker signature of raised IL-6, oncostatin M and C-X-C motif chemokine 8, while in the second step the additionally increased IL-17, IL-12p40/p70, and IL-23 levels signified a bacterial-associated inflammation pattern. ${ }^{57}$ Moreover, the discriminative accuracy for VM of a new CSF biomarker the high-mobility group box 1 protein was studied in 29 EVD-treated neurosurgical patients and performed better than CSF lactate, leucocytes, protein, and glucose with an AUC of $0.83 .{ }^{58}$

Regarding diagnostic modeling, Zheng et al constructed a model-algorithm using routine CSF examinations. ${ }^{59}$ They selected five variables (CSF WBC count, CSF glucose, blood glucose, CSF lactate, and CSF-to-blood glucose ratio) through multivariate analysis. They developed and verified a fitted variable, which excellent performance, an AUC 0.907, at a cut-off value of 0.505 , and an overall concordance rate of $88.6 \%{ }^{59}$

A prediction score was developed in a cross-sectional study for discriminating VM from AM. Their final model comprised of six variables: aneurysmal SAH as primary diagnosis, C-reactive protein $>6 \mathrm{mg} / \mathrm{dL}$, CSF-to-blood glucose ratio $<0.4$, CSF leak status, CSF neutrophil percentage $>50 \%$, CSF lactate $>4 \mathrm{mmol} / \mathrm{L}$ while the respective variable contribution was $1,1,1,1.5,1.5$ and 4 points. If the sum of the points was equal to or higher than 6 , the discrimination was excellent (AUC 0.94). ${ }^{60}$

Finally, the CSF proteome was studied in a rat model of CSF drainage catheter experimental C. acnes infection. The proteome of C. acnes infected rats differed from the aseptic inflammation of the control animals both on day 1 postinsertion and later it evolved differently. ${ }^{61}$

Regarding the sampling site, CSF is regularly drawn via the catheter, if present. Of interest, in a recent study, 141 paired samples were collected, via the EVD and lumbar puncture. The CSF collected from lumbar puncture was twice more likely to fulfill infection criteria (WBC, protein, and lactate were raised and glucose CSF/blood glucose decreased) compared to the EVD sample; this increased LP sensitivity might aid in the exclusion of VM. However, LP collection isolated fewer bacteria. ${ }^{62}$

To conclude, common CSF measurements, ie, WBC count, glucose, and their ratios relative to the corresponding blood values, can often guide diagnosis. However, novel biomarkers and cytokines emerge and hold promise for the future.

\section{Imaging}

Imaging's role for VM diagnosis is mainly limited to exclusion of other pathologies like abscesses. Gadolinium contrastenhanced T1-weighted images can demonstrate ependymal enhancement, whereas diffusion-weighted imaging can show pus collection in the ventricular system. ${ }^{2}$

\section{Microbiological Diagnosis}

Microbiological diagnosis is routinely based on CSF Gram stain and culture. However, their respective sensitivity may be as low as $20 \%$ and $50 \%$, and the administration of antibiotics before CSF sampling may further decrease their diagnostic 
yield. ${ }^{32,35,41}$ Regarding $C$. acnes that is difficult to isolate, the use of anaerobic culturing and the regular prolongation of the culture observation period to 10 days can improve its isolation rate. ${ }^{63,64}$

Various molecular methods, either commercial or in-house, such as nucleic acid amplification tests (NAATs), have been studied and compared with the gold standard, ie, CSF culturing. ${ }^{65-71}$ Compared to the classical microbiology assays, they return positive results sooner, they are less prone to false-negative results as prior antimicrobial therapy minimally affects pathogen recovery, and might reveal novel etiologic microorganisms. However, it should be noted that microorganisms of questionable clinical significance may be identified, as well. ${ }^{70,71}$ Modern NAAT methods have played a supplementary role in CSF microbial culture. ${ }^{68,69}$ The turnaround time varied between the techniques; overall, real-time and next-generation sequencing PCR take less than 24 up to 48 hours to give results. ${ }^{67-71}$ Notably, in a recent study of metagenomic next-generation sequencing of $102 \mathrm{CSF}$ samples, the assay missed 15 culture isolates; however, it identified 22 pathogens, all from suspected VM cases, not detected in culture. Eventually, 10 of these 22 patients had their treatment favorably adjusted. Sequencing also reported coinfections, unidentified by conventional microbiology. ${ }^{71}$

Currently, the only NAAT with FDA clearance for CSF testing (ie, Xpert EV, Cepheid; is the novel syndromic FilmArray meningitis/encephalitis [ME] panel, BioFire Diagnostics, Salt Lake City, UT) ${ }^{72}$ The FilmArray ME directly examines the CSF, without prior handling; however, it mostly targets community pathogens and is not suitable for the detection of the nosocomial pathogens causing VM. ${ }^{72}$ On the other hand, the bacteremia FilmArray panel (Biofire blood panel [BCID]) can identify both skin GP and aerobic GN microorganisms, including nosocomial ones, that are frequently responsible for $\mathrm{VM}^{73}$ A recent study analyzed CSF samples of patients with CNS infections using the BCID panel and reported promising results. ${ }^{74}$ Ninety CSF samples were analyzed with the BCID panel achieving a sensitivity of $77.4 \%$ and specificity of $100 \%$, while the use of lower cut-offs, improved the sensitivity to $83.9 \%$ without any significant impact on a specificity that remained high (98.3\%) ${ }^{74}$ The turnaround time of both ME and BCID panels is much faster than conventional cultures, approximately 1 hour. ${ }^{72,73}$

An alternative technique for the molecular identification of the pathogen is to process an aliquot of a positive CSF culture into a micro/nanofluidic chip platform that contains many genetic targets, species-specific or resistance determinants. The pathogen and resistance pattern detection was expedited by a day and was highly concordant to the phenotype identification through conventional microbiology. ${ }^{75}$

A matrix-assisted laser desorption/ionization time-of-flight mass spectrometry assay was directly applied to Gram smear-positive CSF of meningitis patients. Regarding the post-neurosurgical meningitis group, the GN pathogen was correctly identified in 17/21 specimens compared to the implicated GP microbe detected in just 1/11 samples. ${ }^{76}$

Regarding VPS, the infection frequently escapes the diagnosis based on the classical infection criteria. ${ }^{40}$ Sonication utilizes focal ultrasound to dislodge biofilm bacteria from the surface of explanted materials before prolonged cultures, such as explanted orthopedic and neurosurgical hardware. ${ }^{77-79}$ A recent meta-analysis showed that the sensitivity and specificity of sonication were as high as $87 \%$ and $57 \%$, respectively. ${ }^{80}$ Moreover, sonication was superior to conventional techniques, particularly in coagulase-negative staphylococci infections. ${ }^{81}$

\section{Diagnostic Criteria}

The diagnostic criteria in the literature vary. Apart from the Infectious Diseases Society of America (IDSA) guideline definition, ${ }^{2}$ many authors adopt the nosocomial infections surveillance definition, ${ }^{37}$ which delineate VM as fulfilling, in any case, at least one of the two criteria below: 1) A performed CSF culture or another method, not part of active surveillance testing, has identified a microorganism, 2) The patient presents two of the ensuing a) fever or headache (if they coexist, they count as one element only), b) meningeal signs, c) cranial nerve signs ( $b$ and $c$, not attributed to other causes) and at all events, one of the following: i) Pleocytosis, raised protein, decreased glucose in the CSF, ii) a microorganism distinguished on the CSF Gram stain, iii) a microorganism is identified in the blood by either culture or non-culture testing, iv) serologic diagnosis for the microorganism with single IgM titer or 4-fold raise in dual sera.

There is an array of definitions with a variety of diagnostic items, different laboratory thresholds, and a lack of an objective gold standard for diagnosis. ${ }^{2,19,37,82-84}$ An overview of the diagnostic elements is displayed in Table 1. 


\section{Prevention}

Prevention strategies include a wide spectrum of interventions that are designed to cope with various risk factors of VM. ${ }^{19,85,86}$ Although most of these prevention aspects are recommended and well studied, some are weakly supported by limited or controversial evidence.

\section{Recommendations for the Prevention of VM in Patients with CSF Shunts or Drains Periprocedural Chemoprophylaxis}

Although antimicrobial prophylaxis peri-insertion might favor the selection of resistant pathogens, ${ }^{87,88}$ their administration before the device placement or for a limited period post-insertion (for up to 24-48 hours) is considered, nowadays, as the standard of care in patients undergoing CFS shunt insertion and placement of EVD catheters. ${ }^{2}$ A current Cochrane database review demonstrated that periprocedural prophylactic antimicrobial administration decreased VM rates by approximately $50 \%{ }^{89}$ Of note, in most of the included studies, the prophylactic antibiotics target GP pathogens, although GN bacteria account for about $50 \%$ of the culprit microorganisms. ${ }^{89}$ Moreover, the protracted use of systemic prophylactic antimicrobials is a controversial issue. Leading societies recommend against the prolonged, for the entire duration of catheter placement, administration of antimicrobial prophylaxis due to resistance, ${ }^{88}$ and cost concerns. ${ }^{85}$ Thus, they advocate that a single dose of an antibiotic, selected following local antimicrobial resistance patterns, would suffice. ${ }^{90}$

\section{Silver and Antimicrobial-Impregnated Catheters}

Antimicrobial-impregnated catheters for CSF shunts and drains are typically impregnated with rifampicin combined with either minocycline or clindamycin. Silver-impregnated catheters contain silver as an antimicrobial substance. They were designed to impede colonization of the catheter during placement and were soon found to be effective in decreasing colonization rates. ${ }^{91}$ The efficacy of antimicrobial-impregnated catheters to reduce post-intervention infection rate compared to plain catheters, regarding both CSF shunts and external ventricular drains, is currently supported by the literature. ${ }^{92-94}$ In addition, it seems that this strategy results in significant hospital cost reduction. ${ }^{95}$ Of interest, the available antimicrobialimpregnated catheters contain chemotherapeutics active against GP pathogens, including the commonly occurring coagulasenegative Staphylococcus. Thus, their use tends to decrease the GP-VM events and not the GN ones, which might cause more severe infection. ${ }^{31,93,94}$ Of note, a catheter targeting GP and GN bacteria and containing rifampicin, trimethoprim, and triclosan was not toxic to the rats tested while in vitro mitigated colonization. ${ }^{96}$

\section{Standardized Protocols and Bundles of Care}

Protocolized care (or bundled care) uses a group of applied preventive measures related to the placement and maintenance of EVDs with promising results. In a pilot study, Korinek et al reported that the adoption of a strict, written protocol for EVD insertion, nursing, and surveillance was associated with a significant decrease in the incidence of patient-related ventriculitis and demonstrated the value of proper hand hygiene and limited system manipulation for prolonging drainage duration. ${ }^{86}$

\section{Controversial Topic: External Ventricular Drain Exchange}

External ventricular drains are often colonized after the first seven drainage days. ${ }^{24}$ Moreover, the risk of infection is reported to rise with the increased duration of drainage for the first 7-10 days and afterward plateaued or became less likely. ${ }^{97,98}$ An older study suggested that the scheduled EVD exchange every 5 days decreased the infection rate. ${ }^{99}$ However, Holloway et al reported that if catheters were replaced before 5 days the patients had not presented a lower infection rate compared to the individuals whose catheters were exchanged at more than 5 -day intervals. ${ }^{97}$ Indeed, Wong et al reported, in a randomized controlled trial examining catheter exchange, that the infection rates for the change vs the control group were $7.8 \%$ vs $3.8 \%$, respectively. ${ }^{100}$ In a before-after study, a bundle that successfully decreased the VM infection rate included scheduled catheter exchange among other interventions; however, it was uncertain which bundle element made the difference in the outcome. ${ }^{101}$

Summarizing the evidence, prophylactic catheter exchange at a set interval is not recommended, since it can be used for as long as clinically indicated. In contrast, prophylactic antimicrobial chemotherapy of limited duration, the 
maintenance of a sterile protocol, the meticulous intraventricular catheter handling, the cerebrospinal fluid sampling only when clinically necessary, and the prompt removal of the catheter when no longer needed may all lower the infection risk. Of note, an EVD insertion checklist is, at present, a recommended clinical performance measure. ${ }^{102}$ An overview of prevention studies of the last decade is displayed in Table $2 .^{28,85,101,103-119}$

\section{Treatment}

\section{Pharmacokinetic/Pharmacodynamic Considerations}

Neurosurgical patients who suffer a CNS infection are often critically ill and the hydrophilic antibiotics' pharmacokinetics (such as beta-lactams, aminoglycosides, vancomycin, and daptomycin) is altered compared to general ward patients. ${ }^{120}$ Thus, critically ill patients may warrant loading doses and a higher daily antibiotic dose with therapeutic drug monitoring, which, however, is not widely available for many commonly used antibiotics as yet. ${ }^{121}$

Apart from the dosage, impediments to the entry of the antimicrobials into the CNS are the barriers that shelter the brain and the spinal cord, the blood-brain, blood-spinal cord, and blood-CSF barriers that separate the CNS compartments from the central, blood, compartment. ${ }^{122}$ The degree of antibiotic penetration into the CSF is influenced by both antibiotic physicochemical factors and patient factors. ${ }^{123}$ Unionized, non-protein bound antibiotics with low molecular weight and lipophilic antibiotics (such as quinolones, rifampicin) have enhanced penetration into the CSF which is not inflammation dependent. ${ }^{124}$ CNS inflammation facilitates antibiotic diffusion into CSF due to the opening of the tight junctions of the blood-brain-barrier cells. ${ }^{123}$ However, intense meningeal inflammation that enables elevated CSF antibiotic concentrations is not regularly present in VM; thus, the disease is associated with low drug levels. ${ }^{125,126}$ Among the antimicrobial classes commonly used, the glycopeptides and the beta-lactam are both hydrophilic and ionized. ${ }^{125}$ The glycopeptides, such as vancomycin, due to their hydrophilicity and large molecular size, were considered as having very poor CSF penetration. However, the penetration of vancomycin is not universally low, but variable and unpredictable, and does not correlate with the clinical outcome. ${ }^{127}$ Furthermore, the CSF half-lives of beta-lactams may be prolonged and variable, depending on several factors, such as the rate of CSF production and the CSF volume (including ventricle size), the integrity of blood-barrier, and in case of drainage, the EVD drainage pressure scale and alternations. $^{128}$

In terms of pharmacokinetics (PK), there is a delay in drug entry into the CSF compared to other body compartments, and thus, there is a time lag between the respective peak levels between the blood and the CSF (hysteresis phenomenon), while the CSF to plasma ratio is expected to increase following the initiation of the antibiotic infusion. ${ }^{128}$ Therefore, the best PK parameter, for the assessment of antibiotic penetration into the CSF, is the ratio of the area under the antibiotic concentration curve of the CSF to that of the serum. ${ }^{122,124}$

There are older antibiotics with favorable CSF penetration profiles. Chloramphenicol (penetration of approximately $50 \%$ ) presented treatment results comparable to beta-lactams in meningitis studies. ${ }^{129}$ Intravenous fosfomycin, virtually always combined with other antimicrobials, presents acceptable penetration into the CSF compartment. ${ }^{130}$ Fosfomycin's antimicrobial spectrum covers multidrug-resistant GP and GN bacteria while the cure rate was excellent. ${ }^{131}$ If the intravenous formulation is available, as in many European countries, it might provide a valuable treatment option. ${ }^{132}$

In contrast, the intravenous high $10 \mathrm{mg} / \mathrm{Kg}$ dosing of daptomycin for $\mathrm{VM}$, and a mean of 5.6 days hardly penetrated the CSF compartment. ${ }^{133}$ In addition, a single-dose ceftaroline pharmacokinetic model displayed low drug concentrations, below $0.5 \mathrm{ng} / \mu \mathrm{L}$, and the MIC of most clinically relevant isolates. ${ }^{134}$

Not only is the antimicrobial transfer altered in comparison with the central blood compartment, but the CSF milieu also differs from that of the extracellular space. The CSF has a pH of 7.28-7.32, low sugar and protein content impending the bacterial growth, but, on the other hand, hindering the action of many antibiotics. The former combined with the minimal immune response of the CSF denotes the need for high antimicrobial levels above the minimum inhibitory concentration (MIC) of the pathogen. ${ }^{124,135}$ There are no well-established optimal pharmacodynamic (PD) targets for CNS infections that maximize bacterial killing. ${ }^{123}$

Although the scarcely available data has not pointed to an association between the CSF drug levels and clinical cure or microbial eradication, high antibiotic levels, often $>10 \times$ MIC, may be needed to enable fast bacterial killing. ${ }^{127,136}$ 
Finally, it should be noted that CSF concentrations are just an estimate, a surrogate marker, of the active unbound antibiotic concentration beyond the blood-brain barrier. Studies in animal brain biopsies have shown, despite undetectable CSF levels, levels in brain tissue $10-20 \%$ of the serum levels. ${ }^{137}$

\section{Systemic Treatment-Empirical Therapy}

The initial, empirical treatment of VM has to cover the most common etiological microorganisms considering the local epidemiology. The recent guidelines recommend a combination regimen of vancomycin and an antipseudomonal betalactam (meropenem or cefepime or ceftazidime). ${ }^{2}$ If the patient has a severe beta-lactam allergy, they suggest either meropenem or aztreonam, or ciprofloxacin for GN coverage. ${ }^{2}$ Meropenem is the preferred option in a setting of infections by extended-spectrum beta-lactamase-producing Enterobacterales. ${ }^{138}$ Resistant non-fermenting GN pathogens may need the administration of alternative antimicrobial agents, such as colistin, tigecycline, and novel beta-lactam/betalactamase inhibitors. ${ }^{16}$ The evidence, however, regarding the efficacy of novel beta-lactam/beta-lactamase inhibitors in the setting of CNS infection is yet limited. ${ }^{139,140}$ Moreover, the beta-lactam antimicrobials could be given in much higher doses than those recommended to facilitate their transfer to the CSF. ${ }^{141}$ Parallel to the initiation of empirical antibiotic therapy, prompt removal of the relevant CNS device should regularly be performed. ${ }^{2}$ It should be highlighted that the current recommendation on antimicrobial dosing for CNS infections may lead to subtherapeutic exposures. ${ }^{123}$

\section{Systemic Treatment-Targeted Therapy Gram-Positive Bacteria}

Staphylococcal penicillin, either alone or in combination with another antimicrobial drug, such as rifampicin or fosfomycin, is recommended for the treatment of methicillin-sensitive Staphylococcus aureus and coagulase-negative staphylococci. ${ }^{132}$ Of note, one cannot solely administer either of the latter two drugs to avert the emergence of resistance. ${ }^{131}$ Rifampicin, in particular, is valuable for the treatment of device-associated infections due to its biofilm activity. $^{22}$

The recent IDSA guidelines recommend vancomycin for the treatment of methicillin-resistant staphylococci, while its trough levels should be kept at $15-20 \mu \mathrm{g} / \mathrm{mL} ;{ }^{2}$ however, they suggest a second-line drug if the microorganism's minimal inhibitory concentration is $\geq 1 \mathrm{ng} / \mu \mathrm{L}$. Of the available other options, daptomycin, even at high, doses can fail and ceftaroline, a novel cephalosporin, which is active against methicillin-resistant $S$. aureus, at the double recommended dosing (600mg QDS), might eradicate a susceptible isolate in the CSF and needs further investigation. ${ }^{142}$ However, linezolid presents an advantageous CSF penetration profile and was a reasonable alternative whenever a patient was allergic to vancomycin or the latter had failed. ${ }^{143}$ Although linezolid had not demonstrated mortality benefit compared to vancomycin, it was associated with better microbiological and clinical outcomes. ${ }^{144}$ Considering the vancomycin's limitations some investigators have questioned its value as the first-line drug for staphylococcal VM treatment. ${ }^{145}$

Regarding the antimicrobial chemotherapy of C. acnes, the recent guidelines recommend penicillin $\mathrm{G}^{2}$

\section{Gram-Negative Bacteria}

An antipseudomonal beta-lactam is suggested for the treatment of a susceptible isolate. However, the high prevalence of DTR-GN isolates in many centers around the world has complicated antibiotic choice. ${ }^{16}$ Available intravenous options for these pathogens include aminoglycosides, polymyxins, and tigecycline. ${ }^{16}$ The aminoglycoside and colistin dosing can only be increased by a limited amount due to their narrow therapeutic index. ${ }^{146,147}$ From a practical standpoint, one often adds colistin on meropenem pending the culture results. ${ }^{1}$ Colistin's in vitro efficacy against $A$. baumannii, at regular dosing, might be augmented by the addition of either fosfomycin or sulbactam. ${ }^{148}$ Moreover, fosfomycin in tandem with either aminoglycosides or colistin or tigecycline presented synergistic effects against DTR A. baumannii. ${ }^{149}$ However, the clinical potential of those combinations for the treatment of the infection due to DTR-GN pathogens remains unknown. 


\section{Duration of Systemic Antibiotics}

The antimicrobial chemotherapy duration should last for 10-14 days for coagulase-negative staphylococci or $C$. acnes infection while this timespan could extend up to 21 days for $S$. aureus- or GN-VM. Whenever the cultures continue to be positive, it is suggested that patients should continue treatment for 10-14 days following the last pathogen isolation. ${ }^{2}$

\section{Infusion Strategy}

A possible way to improve the CSF levels of antibiotics with time-dependent killing, such as beta-lactams, could be via dose optimization using continuous or prolonged antimicrobial infusion. At present, there is only preliminary evidence for the benefit of administering continuous or prolonged over intermittent antibiotic infusion for the treatment of VM, ${ }^{150}$ while this practice has been studied for the management of sepsis. ${ }^{151,152}$ The prolonged, over 4 hours, meropenem infusion of $2 \mathrm{~g}$ TDS in neurocritical patients with suspected VM resulted in CSF levels of $<2 \mathrm{ng} / \mu \mathrm{L}$, which are insufficient to cover marginally sensitive pathogens. ${ }^{153}$ The continuous infusion of ceftolozane-tazobactam has been recently evaluated and enabled high drug levels in the CSF. ${ }^{140}$ Similar to the above, the administration of higher than the recommended dose of cefazolin by continuous delivery resulted in free medicine's CSF levels always superior to MIC. ${ }^{154}$ In a recent study, authors have administered cloxacillin or cefazolin via $\mathrm{CI}$ to the majority of 17 staphylococcal meningitis patients and only two cloxacillin-treated individuals stopped the drug due to clinical failure. ${ }^{150}$ Indeed, the continuous infusion of cefazolin achieved high enough CSF levels that regularly exceed the epidemiological cut-off values. ${ }^{150}$ Contrary to the above, the continuous infusion of both meropenem and vancomycin resulted in low CSF levels. ${ }^{155}$ Finally, therapeutic drug monitoring during the continuous infusion may facilitate the achievement of higher serum drug concentrations while likely mitigating antibiotic toxicity. ${ }^{152,156}$ For an overview of systemic therapy, we refer the reader to Table S1. ${ }^{2}$, 22, 129, 131, 139, 146, 150, 157-164

\section{Intraventricular/Intrathecal Therapy}

Generally, beta-lactams have a wide therapeutic index that allows aggressive dosing to be implemented, however, other antimicrobials, such as colistin and aminoglycosides, have a more narrow therapeutic index. ${ }^{146,147}$ An alternative to high intravenous dosing administration that bypasses the blood-brain and blood-CSF barriers and may overcome the limited penetration of the antibiotics into the CSF and raise the respective drug concentrations is the direct instillation of antimicrobials into the CSF compartment, added on the intravenously administered drug. ${ }^{136}$ The antibiotics regularly administered through the IVT (or IT) route are vancomycin, polymyxin B, colistin, aminoglycosides, and, more recently, daptomycin and tigecycline. ${ }^{136}$ The drug is administered either through the intraventricular route (IVT) or the lumbar sac, the intrathecal route (IT). ${ }^{15}$ Indeed, IVT(IT) antibiotic administration adjunct to the intravenous one resulted in therapeutic CSF drug levels. ${ }^{126,165}$ Of note, the CSF space demonstrates a concentration gradient between the ventricles and the lumbar subarachnoid fluid and, therefore, the direct IVT delivery differs from the direct IT administration. ${ }^{166}$

The current IDSA guidelines suggest using adjunct IVT(IT) to IV antimicrobial administration if the patient did not clinically improve on solely systemic treatment or the disease was caused by a DTR microorganism, notably A. baumannii. ${ }^{2,90}$ IVT(IT) salvage therapy, for clinical or bacteriological failure after a mean of seven days IV-only treatment, was successful in expediting microbial eradication. ${ }^{167}$ Regarding the management of DTR pathogens, carbapenem-resistance status seemed to justify IVT(IT) treatment for both the CSF sterilization and mortality outcomes; however, the quality of data was very low. ${ }^{15}$ Direct comparison between combined IVT/IV and IV only therapy favored the joint delivery in terms of faster bacterial eradication, better CSF microscopy recovery, and shorter hospital length of stay; however, the results were from a retrospective single-center study and need further evaluation. ${ }^{168}$

IVT vancomycin had been investigated in a case series of 45 CSF shunt- and 5 EVD-treated patients. Despite the inconsistent CSF levels measured after the regular, non-infant, dose of $20 \mathrm{mg}$, the treatment cured the infection in all EVD- and the vast majority of shunt-associated cases. ${ }^{169}$ IVT daptomycin has been used to complement the IV administration as the latter often failed to clear the CSF. ${ }^{164,170}$

Adjunct IVT gentamicin has been retrospectively examined in 31 post-neurosurgery patients. ${ }^{171}$ The participants had received a variety of IV antimicrobials and were separated into two groups: the one had been administered solely IV 
treatment while the other IV plus IVT gentamicin. The majority of the latter group received the drug late for failure to sterilize the CSF. The addition of IVT gentamicin cured all the patients with no relapses. ${ }^{171}$ This sequential addition of IVT was evident in another study where the authors used amikacin or gentamicin or colistin after a time lag of 5-63 days from the initial pathogen isolation. ${ }^{172}$ Combined IVT(IT) to IV colistin can cure VM over $80 \%$ of the times delivered, at a regular dose of 125000iu QD for a median of 18 days. ${ }^{173}$ Of note, the European Medicines Agency, stating poor penetration, has approved colistin at a dose of $10 \mathrm{mg}$ (125000i.u.) for IVT(IT) use. Up to this date, colistin remains the solely approved drug for the IVT treatment of VM. ${ }^{174}$ In a retrospective study, adjunct IVT(IT) to IV polymyxin B was compared to routine just IV drug for DTR A. baumannii and resulted in a $91.3 \%$ to $18.4 \%$ eradication rate and improved mortality $(8.7 \%$ vs $55.3 \%) .{ }^{175}$ Tigecycline has been recently introduced as adjunct IVT to IV tigecycline therapy; ${ }^{176,177}$ in a recent case series the antimicrobial combined with IVT colistin often sterilized the CSF while the treatment lasted for 9-45 days; however, this is preliminary data. ${ }^{176}$

\section{IVT Dosing}

IVT(IT) dosing varies with the ventricle size and the CSF output; however, once-daily dosing, at the suggested drug doses, usually suffices. ${ }^{1,2,136}$ Meanwhile, the current IDSA guidelines suggest drug CSF levels 10-fold to 20-fold the MIC of the isolate. For a CSF volume of approximately $250 \mathrm{~mL}$, the IVT administration of $5 \mathrm{mg}$ of gentamicin or tobramycin and $30-50 \mathrm{mg}$ of amikacin, is expected to attain a CSF Cmax/MIC $>10$ for susceptible pathogens and, regardless of the averse acidic CSF milieu, to achieve maximal killing. ${ }^{123}$ Regarding the IVT administration of colistin, the attainment of AUC/MIC $>50$ that has been related to maximal antibacterial activity against susceptible isolates (MIC, $2 \mathrm{mg} / \mathrm{L}$ ), is most probable after the delivery of $10 \mathrm{mg}$, in a single or divided dose. ${ }^{178}$ Concerning tigecycline, it should be noted that to date, there are no available data from PD studies in patients with CNS infections. ${ }^{123}$ IVT administration of tigecycline has been reported in case reports or small case series with doses up to $8 \mathrm{mg} / \mathrm{day}$, but not based on PK/PD target attainment. ${ }^{123,176}$

Notably, the antimicrobial CSF concentrations are not certainly associated with outcome or toxicity. ${ }^{179}$ Therefore, therapeutic drug monitoring might be a useful practice whenever there is a failure of IVT(IT) treatment to sterilize the CSF or a need for prolonged therapy or suspicion of toxicity. ${ }^{2,136,179}$ However, in a small care series, an IVT colistin load of $40 \mathrm{mg}$ followed by de-escalation to the recommended 10mg dose QD or every 48 hours always sterilized the CSF in $1-5$ days. ${ }^{180}$

\section{Duration of IVT Antibiotic Treatment}

The length of IVT delivery varied between the available studies (mostly case reports of individualized, and not protocolized treatment) while the total treatment duration has often not been specified. ${ }^{15}$ The suggested minimum installation duration was 2-3 days after CSF sterility although the overall treatment may last for up to 3 weeks following culture negativity. ${ }^{179}$ In a retrospective cohort study, although the 105 patients received IVT for a total of 5-6 days, they had their CSF sterilized at a rate of $88.4 \%$ and a positive culture persistence/recurrence rate at $9.5 \% .{ }^{181}$

\section{Side Effects}

From a technical standpoint, the clamping of the drain for 15-60 minutes ensures the delivery and the equilibration of the antimicrobial dose. ${ }^{2}$ Regarding the antibiotic instilled, it should be sterile, single-dose, free of preservatives to mitigate toxicity, although in many of the literature reports there is no data about the presence of any preservatives in the antibiotic formulation delivered. ${ }^{136,182}$ The IVT therapeutic modality is linked to side effects. It requires catheter handling with the inherent risk of secondary infections from the daily manipulation of the catheter. ${ }^{1}$ Moreover, in a recent meta-analysis, 223 patients with GN-VM treated with IVT(IT) demonstrated a high local complication rate, of $13 \%$; the prime concerns comprise chemical meningitis [11\% (95\% CI 7-17\%)] and seizures $[7 \%(95 \%$ CI $4-12 \%)] .{ }^{182}$ However, many patients were either comatose or sedated and the clinical signs of toxicity might have been unnoticed.

The above side effects suggest that IVT antibiotic delivery should be reserved for treating DTR-GN pathogens, where it might improve the outcome. ${ }^{15}$

An overview of IVT(IT) is displayed in Table 3. 


\section{Neurosurgical Perspective}

Although the optimal antimicrobial scheme and the duration of treatment remain to be identified, the management frequently involves neurosurgical interventions. To begin with, EVDs frequently fail in patients with ventricular empyema due to drain malfunction from tissue membrane-like debris and high fluid viscosity of fibrin. In these cases, endoscopic evacuation using a side-cutting aspiration device could be of help. ${ }^{183}$ The technique can be supplemented by a septostomy using biopsy forceps, ventricular lavage with saline, and intraventricular antibiotic administration. ${ }^{184}$ Endoscopic evacuation and lavage advantages are safe debris removal, targeted high-flow irrigation and tissue sampling, and microabscess destruction. ${ }^{184}$ Endoscopic evacuation and irrigation indications are not clear, and currently, neuroendoscopy has been used to treat primarily purulent meningitis when intravenous antibiotics and EVDs fail. ${ }^{184}$ The results are frequently encouraging, with a good outcome in most of the cases and moderate results regarding shunt dependence. ${ }^{185,186}$ However, further high-quality research is required to elucidate the role of neuroendoscopy in managing post-neurosurgical infections. About DTR A. baumannii, the combined use of IVT irrigation with colistin solution, up to clear return, and IVT colistin resulted in negligible infection relapse and an $80 \%$ success rate. ${ }^{187}$

In cases of implants, eradication of VM is unlikely without implant removal. ${ }^{1,222}$ Notwithstanding, a significant problem that should be considered in managing post-neurosurgical ventriculitis is that neurosurgical patients are frequently device-dependent. Permanent devices could be re-implanted after a variable period and negative serial cultures in a one- or two-stage process. ${ }^{1,2,22}$ The one-stage process involves device removal and implantation of a new one at a single operation. ${ }^{1,2,22}$ In the two-stage process, the device removal is followed by a device-free period before device reimplantation. ${ }^{1,2,22}$ There is plenty of controversy regarding the optimal timing of re-implantation, but the new device could be safely re-implanted 10 to 15 days after the infection eradication based on negative cultures and without antibiotic cessation. ${ }^{1,2,22}$

\section{Prognosis}

The prognosis can be dismal; the in-hospital mortality burden is increased and varies from $9.3 \%$ to as high as $40.3 \%{ }^{35,188}$ Settings with resistant GN bacteria are associated with higher mortality ${ }^{15,187}$ compared with settings of less resistant pathogens; ${ }^{35}$ however, direct comparison is lacking. Apart from mortality and regardless of the causative agent, adverse neurological outcome (dependent daily living, vegetative state, and death) was evident in about $60 \%$ of the patients assessed. ${ }^{35,101}$ The factors independently implicated with mortality were unhealthy neurological examination, admission Glasgow Coma Scale $<8$, age older than 40 years of age, coexisting diseases, CSF pleocytosis over 200 cells/ $\mu \mathrm{L}$, the presence of EVD, and failure to sterilize the CSF. ${ }^{35,188-190}$ Of interest, mortality following postoperative VM in a DTR setting was independently associated with the isolation of $A$. baumannii and the administration of inappropriate empirical treatment. ${ }^{17}$

In a cohort of patients with intracranial hemorrhage, the development of VM presented an additional and independent factor that further worsened their prognosis. ${ }^{191,192} \mathrm{VM}$ patients compared with non-VM individuals had higher mortality and doubled both the hospital length of stay (median stay of 31 vs 16 days) and cost of care. ${ }^{191}$ Moreover, good neurological recovery occurred significantly less often, in VM patients compared to their non-VM counterparts (17.5\% vs $71 \%) .{ }^{192}$

\section{Expert Opinion}

The presence of VM can lead to daunting sequelae as the patients suffer increased mortality and functional compromise. Diagnosis might be elusive whenever no pathogen is isolated from the CSF, often due to prior administration of antimicrobial chemotherapy or infections with slow-growing, biofilm-forming microorganisms, such as $S$. epidermidis or C. acnes. There is no diagnostic gold standard and the current criteria do not confidently differentiate VM from aseptic inflammation (Table 1). Novel experimental diagnostic methods, such as proteomics, which exploit the synthesis and the daily evolution of CSF proteins can improve diagnostic accuracy. Meanwhile, the expansion of molecular libraries and the technical refinements of novel microbiological assays gradually replace conventional microbiology, although they still warrant further validation. The molecular identification of the pathogens themselves, and their relevant resistance 
Table I Diagnostic Criteria for External Ventricular Drain-Associated Ventriculomeningitis

\begin{tabular}{|c|c|c|c|c|c|c|}
\hline Considerations & IDSA $^{2}$ & $\mathrm{CDC}^{37}$ & Lozier $\$ 19$ & Mounier $^{82}$ & Gozal $^{\S 83}$ & Honda $^{84}$ \\
\hline Fever* & Yes & Yes & Yes & No & Yes & No \\
\hline Clinical meningitis symptoms and signs \# & Yes & Yes & Yes & No & No & No \\
\hline Suggestive CSF profile & Yes & No/yes" & Yes & No & Yes $^{\# \#}$ & Yes ${ }^{\pi T \pi}$ \\
\hline CSF culture required for diagnosis & Yes & Yes/no" & Yes (or Gram stain) & Yes** & Yes & Yes \\
\hline Quantity of microorganism growth required & Any & Any & Any & Any & Any & Any \\
\hline Aseptic meningitis excluded & Yes & No & Yes & Yes & Yes & Yes \\
\hline Antibiotic pretreatment considered & No & Yes & No & No & No & No \\
\hline Antimicrobials targeting CNS & No & No & No & Yes & No & No \\
\hline Time required after EVD insertion & No & No & No & No & No & $>48$-hours \\
\hline Interval from catheter removal for a valid diagnosis & No & No & No & No & Up to 72 hours & Up to 5 days \\
\hline
\end{tabular}

Note: *May represent other focus of infection. ${ }^{\#} \mathrm{Can}$ be absent due to severity of the primary disease. "BBy the criterion I of the definition/by the criterion $2 .{ }^{8} \mathrm{Definitions}$ of ventriculitis. **Two CSF samples necessary for skin flora microorganisms. ${ }^{\#}$ CSF glucose $<50 \mathrm{mg} / \mathrm{dL}$ or CSF glucose to same-day serum glucose ratio < $50 \%$. "TाTequired only to consider skin flora.

Abbreviations: CDC, Center for Disease Control and Prevention; CNS, central nervous system; CSF, cerebrospinal fluid; EVD, external ventricular drain; IDSA, Infectious Diseases Society of America. 
Table 2 Prevention Studies Reporting Incidence

\begin{tabular}{|c|c|c|c|c|c|c|c|c|c|c|c|c|c|c|}
\hline \multirow{2}{*}{$\begin{array}{l}\text { First Author, } \\
\text { Year; Study; } \\
\text { Period; } \\
\text { Country; } \\
\text { Reference }\end{array}$} & \multirow[t]{2}{*}{ Device } & \multirow{2}{*}{$\begin{array}{l}\text { Catheter } \\
\text { Type }\end{array}$} & \multirow{2}{*}{$\begin{array}{l}\text { Hand } \\
\text { Hygiene } \\
\text { Enhanced; } \\
\text { Hand } \\
\text { Hygiene } \\
\text { Compliance } \\
\text { Monitoring; } \\
\text { Educational } \\
\text { Program } \\
\text { and/or } \\
\text { Checklist }\end{array}$} & \multicolumn{4}{|c|}{ Item(s) Related to Insertion } & \multicolumn{4}{|c|}{ Items Related to Manipulation } & \multirow{2}{*}{$\begin{array}{l}\text { Routine } \\
\text { Catheter } \\
\text { Exchange; } \\
\text { Catheter } \\
\text { Removal }\end{array}$} & \multirow{2}{*}{$\begin{array}{l}\text { VM } \\
\text { Rate } \\
\text { Before/ } \\
\text { CG }\end{array}$} & \multirow{2}{*}{$\begin{array}{l}\text { VM } \\
\text { Rate } \\
\text { AfterI } \\
\text { IG }\end{array}$} \\
\hline & & & & $\begin{array}{l}\text { Antibiotic } \\
\text { Prophylaxis; } \\
\text { Patient Skin } \\
\text { Antisepsis }\end{array}$ & $\begin{array}{l}\text { Head Hair } \\
\text { Management }\end{array}$ & $\begin{array}{l}\text { SC } \\
\text { Tunneling; } \\
\text { Length }\end{array}$ & Other & $\begin{array}{l}\text { Aseptic } \\
\text { Management }\end{array}$ & $\begin{array}{l}\text { Dressing } \\
\text { Change; } \\
\text { Type }\end{array}$ & $\begin{array}{l}\text { CSF } \\
\text { Sampling } \\
\text { Frequency }\end{array}$ & Other & & & \\
\hline $\begin{array}{l}\text { Walek; 202I; } \\
\text { Retrospective; } \\
\text { 2007-2019; } \\
\text { USA; }^{103}\end{array}$ & EVD & $\begin{array}{l}\text { Plain; AIC } \\
\text { only after } \\
\text { suspected } \\
\text { or proven } \\
\text { VM }\end{array}$ & Yes; yes; yes & No; yes & Clipping & Yes; NA & $\begin{array}{l}\text { Sterile } \\
\text { implantation; all } \\
\text { OR doors } \\
\text { closed strategy }\end{array}$ & Yes & $\begin{array}{l}\text { No dressing, } \\
\text { unless oozing } \\
\text { from site }\end{array}$ & $\begin{array}{l}\text { Only if } \\
\text { suspected } \\
\text { VM }\end{array}$ & $\begin{array}{l}\text { Aseptic management of } \\
\text { unintended } \\
\text { disconnection; aseptic } \\
\text { change of full collection } \\
\text { reservoir }\end{array}$ & $\begin{array}{l}\text { No; as soon as } \\
\text { possible }\end{array}$ & $\begin{array}{l}6.71 \\
1000 \\
\text { EVD } \\
\text { days }\end{array}$ & $\begin{array}{l}21 \\
1000 \\
\text { EVD } \\
\text { days* }\end{array}$ \\
\hline $\begin{array}{l}\text { Thien; 2019; } \\
\text { Prospective, } \\
\text { following } \\
\text { retrospective } \\
\text { audit; 2014-16; } \\
\text { USA; }{ }^{104}\end{array}$ & EVD & $\begin{array}{l}\text { Plain, SIC, } \\
\text { and AIC }\end{array}$ & NS; no; no & $\begin{array}{l}\text { Single dose } \\
\text { before; scrub } \\
\text { with } \\
\text { Hexodane } \\
\text { followed by } \\
\text { Cetrimide } 1 \% \\
\text { and povidone } \\
\text { iodine }\end{array}$ & $\begin{array}{l}\text { At least } 1 / 4 \\
\text { head shave }\end{array}$ & Yes; $\geq 5 \mathrm{~cm}$ & $\begin{array}{l}\text { Double gloves } \\
\text { and change } \\
\text { outer glove } \\
\text { before handling } \\
\text { EVD }\end{array}$ & Yes & $\begin{array}{l}\text { Elective } \\
\text { change at } 4 \\
\text { days; plain }\end{array}$ & $\begin{array}{l}\text { According } \\
\text { to the level } \\
\text { of suspicion }\end{array}$ & $\begin{array}{l}\text { EVD clamped when } \\
\text { handled or patient is } \\
\text { mobilized; drainage bag } \\
\text { changed when } 3 / 4 \text { full }\end{array}$ & $\begin{array}{l}\text { Optional if } \\
\text { colonized or } \\
\text { after } 21 \text { days; } \\
\text { within } 10 \text { days if } \\
\text { feasible }\end{array}$ & $4.8 \%$ & $2 \%$ \\
\hline $\begin{array}{l}\text { Yang Li; 2019; } \\
\text { prospective; } \\
\text { 2016-18 } \\
\text { China; }^{105}\end{array}$ & EVD & NS & Yes; no; yes & $\begin{array}{l}\text { Single dose } \\
\text { before; } \mathrm{CHX} \\
\text { antisepsis }\end{array}$ & NS & NS & - & Yes & $\begin{array}{l}\text { Changed } \\
\text { every } 2 \text { days; } \\
\text { NA }\end{array}$ & $\begin{array}{l}\text { Every } 2 \\
\text { days for } \\
\text { culturing }\end{array}$ & $\begin{array}{l}\text { Daily drainage bag } \\
\text { emptying }\end{array}$ & NS & $5.48 \%$ & $2.62 \% *$ \\
\hline $\begin{array}{l}\text { Ates; 2020; } \\
\text { before-after; } \\
201 \mathrm{I}-13 ; \\
\text { Turkey; }{ }^{106}\end{array}$ & VPS & AIC & Yes; yes; yes & $\begin{array}{l}\text { Yes; } \mathrm{CHX} \\
\text { antisepsis }\end{array}$ & Shave & $\begin{array}{l}\text { By } \\
\text { definition; } \\
\text { NA }\end{array}$ & $\begin{array}{l}\text { OR doors } \\
\text { closed }\end{array}$ & Yes & $\begin{array}{l}\text { Changed } 48 \\
\text { hours later; } \\
\text { NS }\end{array}$ & NA & NA & NA & $6.8 \%$ & $2,6 \%{ }^{*}$ \\
\hline $\begin{array}{l}\text { Whyte; 2020; } \\
\text { before-after; } \\
\text { 2014-15 and } \\
\text { 2017; USA; }{ }^{107}\end{array}$ & $\begin{array}{l}\text { EVD, } \\
\text { SGD, } \\
\text { SDD }\end{array}$ & NA & NS; NS; yes & $\begin{array}{l}\text { Started } \\
\text { before, <48- } \\
\text { hour } \\
\text { prophylaxis; }\end{array}$ & Clipping & NS & - & Yes & $\begin{array}{l}\text { When loose } \\
\text { or soiled; } \\
\text { CHX- eluting }\end{array}$ & NS & - & NS & $5.5 \%$ & $5.6 \%$ \\
\hline $\begin{array}{l}\text { Hussein; 2019; } \\
\text { before-after; } \\
\text { 2014-17; } \\
\text { Israel; } ;\end{array}$ & $\begin{array}{l}\text { EVD, } \\
\text { LD, ICP }\end{array}$ & NA & Yes; yes; yes & $\begin{array}{l}\text { Yes, } \\
\text { unspecified } \\
\text { timing; NS }\end{array}$ & NS & NS & $\begin{array}{l}\text { OR insertion } \\
\text { for EVD, ICP }\end{array}$ & Yes & NS & $\begin{array}{l}\text { Only if VM } \\
\text { suspected }\end{array}$ & $\begin{array}{l}\text { MDR-carriers' } \\
\text { cohorting; Daily catheter } \\
\text { assessment }\end{array}$ & $\begin{array}{l}\text { No; as soon as } \\
\text { possible }\end{array}$ & $\begin{array}{l}17.3 / \\
1000 \\
\text { catheter } \\
\text { days }\end{array}$ & $\begin{array}{l}9.21 \\
1000\end{array}$ \\
\hline
\end{tabular}


Table 2 (Continued).

\begin{tabular}{|c|c|c|c|c|c|c|c|c|c|c|c|c|c|c|}
\hline \multirow{2}{*}{$\begin{array}{l}\text { First Author, } \\
\text { Year; Study; } \\
\text { Period; } \\
\text { Country; } \\
\text { Reference }\end{array}$} & \multirow[t]{2}{*}{ Device } & \multirow{2}{*}{$\begin{array}{l}\text { Catheter } \\
\text { Type }\end{array}$} & \multirow{2}{*}{$\begin{array}{l}\text { Hand } \\
\text { Hygiene } \\
\text { Enhanced; } \\
\text { Hand } \\
\text { Hygiene } \\
\text { Compliance } \\
\text { Monitoring; } \\
\text { Educational } \\
\text { Program } \\
\text { and/or } \\
\text { Checklist }\end{array}$} & \multicolumn{4}{|c|}{ Item(s) Related to Insertion } & \multicolumn{4}{|c|}{ Items Related to Manipulation } & \multirow{2}{*}{$\begin{array}{l}\text { Routine } \\
\text { Catheter } \\
\text { Exchange; } \\
\text { Catheter } \\
\text { Removal }\end{array}$} & \multirow{2}{*}{$\begin{array}{l}\text { VM } \\
\text { Rate } \\
\text { Before/ } \\
\text { CG }\end{array}$} & \multirow{2}{*}{$\begin{array}{l}\text { VM } \\
\text { Rate } \\
\text { After/ } \\
\text { IG }\end{array}$} \\
\hline & & & & $\begin{array}{l}\text { Antibiotic } \\
\text { Prophylaxis; } \\
\text { Patient Skin } \\
\text { Antisepsis }\end{array}$ & $\begin{array}{l}\text { Head Hair } \\
\text { Management }\end{array}$ & $\begin{array}{l}\text { SC } \\
\text { Tunneling; } \\
\text { Length }\end{array}$ & Other & $\begin{array}{l}\text { Aseptic } \\
\text { Management }\end{array}$ & $\begin{array}{l}\text { Dressing } \\
\text { Change; } \\
\text { Type }\end{array}$ & $\begin{array}{l}\text { CSF } \\
\text { Sampling } \\
\text { Frequency }\end{array}$ & Other & & & \\
\hline $\begin{array}{l}\text { Sweeny; 2019; } \\
\text { Retrospective } \\
\text { cohort; 2012- } \\
18 ; \text { USA; }{ }^{108}\end{array}$ & VPS & Plain & NS; NS; yes & $\begin{array}{l}\text { Before and up } \\
\text { to } 24 \text { hours; } \\
\mathrm{CHX} \\
\text { antisepsis }\end{array}$ & NS & $\begin{array}{l}\text { By } \\
\text { definition; } \\
\text { NA }\end{array}$ & $\begin{array}{l}\mathrm{CHX} \text { antisepsis } \\
\text { I2h before } \\
\text { operation; } \\
\text { Limited traffic } \\
\text { in OR } \\
\text { Double gloves } \\
\text { and change } \\
\text { outer glove } \\
\text { before handling } \\
\text { hardware }\end{array}$ & NS & NS & NA & NA & NA & $8.8 \%$ & $5.6 \%$ \\
\hline $\begin{array}{l}\text { Katzir; 2019; } \\
\text { retrospective } \\
\text { cohort; 2010- } \\
15 ; \text { Israel; }\end{array}$ & EVD & AIC & NS; NS; NS & $\begin{array}{l}\text { Single dose } \\
\text { before; NS }\end{array}$ & NS & Yes; $\geq 5 \mathrm{~cm}$ & OR insertion & Yes & $\begin{array}{l}\text { Every } 2 \text { days; } \\
\text { semi- } \\
\text { occlusive } \\
\text { adhesive }\end{array}$ & NA & NA & $\begin{array}{l}\text { Every } 5 \text { days vs } \\
\text { clinically } \\
\text { indicated; NS }\end{array}$ & $32 \%$ & $8 \%$ \\
\hline $\begin{array}{l}\text { Mallucci; 2019; } \\
\text { Single blinded } \\
\text { RCT; 2013-17; } \\
\text { UK//reland; }{ }^{85}\end{array}$ & $\begin{array}{l}\text { VP } \\
\text { shunt }\end{array}$ & $\begin{array}{l}\text { Plain vs } \\
\text { AIC vs SIC }\end{array}$ & NS; NS; NS & $\begin{array}{l}\text { Before was } \\
\text { standard, } \\
\text { further NS; } \\
\text { NS }\end{array}$ & NS & NS & NS & NS & NS & NA & NA & NA & $6 \%$ & $\begin{array}{l}2 \% * \\
\text { AIC/ } \\
\text { IG vs } \\
6 \% \\
\text { SIC/IG }\end{array}$ \\
\hline $\begin{array}{l}\text { Roethlisberger; } \\
\text { 2018; Single- } \\
\text { blinded RCT } \\
\text { Trial; 2013-16; } \\
\text { Switzerland;" }{ }^{\circ}\end{array}$ & EVD & SIC & NS; NS; NS & $\begin{array}{l}\text { Single-dose, } \\
\text { before skin } \\
\text { incision; yes }\end{array}$ & $\begin{array}{l}\text { Hemicranial } \\
\text { clipping }\end{array}$ & $5 \mathrm{~cm}$ & OR indertion & NS & $\begin{array}{l}\text { If bleeding } \\
\text { I2hs post- } \\
\text { operation or } \\
\text { every } 5 \text { days; } \\
\text { non-CHX- } \\
\text { adhesive (CG) } \\
\text { vs CHX- } \\
\text { containing (IG) }\end{array}$ & NS & $\begin{array}{l}\text { Dressing edges secured } \\
\text { by surgical stapler }\end{array}$ & NS & $26 \%$ & $14 \%^{\#}$ \\
\hline
\end{tabular}




\begin{tabular}{|c|c|c|c|c|c|c|c|c|c|c|c|c|c|c|}
\hline $\begin{array}{l}\text { Omrani; 2018; } \\
\text { Retrospective } \\
\text { cohort; 2009- } \\
\text { 15; UK;"' }\end{array}$ & $\begin{array}{l}\text { VPS, } \\
\text { VAS, } \\
\text { VPS }\end{array}$ & AIC & NS; NS; Yes & $\begin{array}{l}\text { Yes; Povidone } \\
\text { iodine scrub }\end{array}$ & Clipping & $\begin{array}{l}\text { By } \\
\text { definition; } \\
\text { NA }\end{array}$ & $\begin{array}{l}\text { OR insertion; } \\
\text { Restricted } \\
\text { access; Double } \\
\text { glove changed } \\
\text { before } \\
\text { assembling } \\
\text { shunt and } \\
\text { inserting } \\
\text { ventricular } \\
\text { catheter }\end{array}$ & NS & NS & NA & NS & NA & $5.43 \%$ & $3.27 \%$ \\
\hline $\begin{array}{l}\text { Ershova;, 2018; } \\
\text { Prospective; } \\
\text { 20II-16; } \\
\text { Russia;" }{ }^{\prime 2}\end{array}$ & EVD & NS & Yes; yes; yes & $\begin{array}{l}\text { Single } \\
\text { anesthesia } \\
\text { induction } \\
\text { dose; } \mathrm{CHX} \\
\text { antisepsis }\end{array}$ & NS & NS & $\begin{array}{l}\text { Sterile } \\
\text { implantation, } \\
\text { only by clear } \\
\text { indications }\end{array}$ & Yes & NS & NS & $\begin{array}{l}\text { Minimization of } \\
\text { disconnections }\end{array}$ & $\begin{array}{l}\text { No; as soon as } \\
\text { possible }\end{array}$ & $\begin{array}{l}22.2 \\
\text { cases } \\
\text { per } 1000 \\
\text { EVD } \\
\text { days }\end{array}$ & $\begin{array}{l}13.5 \\
\text { cases } \\
\text { per } \\
1000 \\
\text { EVD } \\
\text { days }\end{array}$ \\
\hline $\begin{array}{l}\text { Bashir; 2016; } \\
\text { Retrospective; } \\
\text { 2003-9; } \\
\text { Denmark; '13 }\end{array}$ & VPS & Plain & NS; NS; NS & $\begin{array}{l}\text { Vancomycin, } \\
980 \mathrm{mg} \text { IV and } \\
20 \mathrm{mg} \text { IVT } \\
\text { before; CHX } \\
\text { antisepsis }\end{array}$ & Shaving & $\begin{array}{l}\text { By } \\
\text { definition; } \\
\text { NA }\end{array}$ & $\begin{array}{l}\text { Limited traffic } \\
\text { in the OR; } \\
\text { Glove change } \\
\text { before shunt } \\
\text { handling }\end{array}$ & NS & NS & NA & NA & NA & $11.8 \%$ & $9.8 \%$ \\
\hline $\begin{array}{l}\text { Chatzi; 2014; } \\
\text { before-after; } \\
\text { Greece; }{ }^{\prime 01}\end{array}$ & EVD & Plain & Yes; yes; yes & $\begin{array}{l}30 \text { minutes } \\
\text { prior to and } \\
6-8 \mathrm{hr} \text { after } \\
\text { insertion }\end{array}$ & Shaving & Yes; $\geq 5 \mathrm{~cm}$ & OR insertion & Yes & Daily; plain & $\begin{array}{l}\text { If clinically } \\
\text { indicated }\end{array}$ & $\begin{array}{l}\text { EVD unblocking was } \\
\text { avoided or, otherwise, } \\
\text { performed distally }\end{array}$ & $\begin{array}{l}\text { Aiming at } \\
7^{\text {th }} \text { drainage day; } \\
\text { as soon as } \\
\text { possible }\end{array}$ & $28 \%$ & 10.5\%* \\
\hline $\begin{array}{l}\text { Camacho; 2013; } \\
\text { before--after; } \\
\text { 2007-10; } \\
\text { Brasil;' '14 }\end{array}$ & EVD & NA & Yes; yes; yes & $\begin{array}{l}\text { Before and up } \\
\text { to } 24 \text { hours } \\
\text { post-insertion; } \\
\mathrm{CHX} \\
\text { antisepsis }\end{array}$ & $\begin{array}{l}\text { Whole scalp } \\
\text { clipping }\end{array}$ & $5 \mathrm{~cm}$ & $\begin{array}{l}\text { OR insertion; } \\
\text { semirecumbent } \\
\text { position; }\end{array}$ & Yes & $\begin{array}{l}\text { Daily dressing } \\
\text { changes and } \\
\text { head } \\
\text { wrapping by } \\
\text { neurosurgery } \\
\text { residents }\end{array}$ & $\begin{array}{l}\text { Only when } \\
\text { infection is } \\
\text { suspected }\end{array}$ & $\begin{array}{l}\text { Avoidance of catheter } \\
\text { unblocking }\end{array}$ & $\begin{array}{l}\text { No; If the system } \\
\text { integrity is } \\
\text { violated or as } \\
\text { soon as possible }\end{array}$ & $9.5 \%$ & $4.8 \%$ \\
\hline
\end{tabular}


Table 2 (Continued).

\begin{tabular}{|c|c|c|c|c|c|c|c|c|c|c|c|c|c|c|}
\hline \multirow{2}{*}{$\begin{array}{l}\text { First Author, } \\
\text { Year; Study; } \\
\text { Period; } \\
\text { Country; } \\
\text { Reference }\end{array}$} & \multirow[t]{2}{*}{ Device } & \multirow{2}{*}{$\begin{array}{l}\text { Catheter } \\
\text { Type }\end{array}$} & \multirow{2}{*}{$\begin{array}{l}\text { Hand } \\
\text { Hygiene } \\
\text { Enhanced; } \\
\text { Hand } \\
\text { Hygiene } \\
\text { Compliance } \\
\text { Monitoring; } \\
\text { Educational } \\
\text { Program } \\
\text { and/or } \\
\text { Checklist }\end{array}$} & \multicolumn{4}{|c|}{ Item(s) Related to Insertion } & \multicolumn{4}{|c|}{ Items Related to Manipulation } & \multirow{2}{*}{$\begin{array}{l}\text { Routine } \\
\text { Catheter } \\
\text { Exchange; } \\
\text { Catheter } \\
\text { Removal }\end{array}$} & \multirow{2}{*}{$\begin{array}{l}\text { VM } \\
\text { Rate } \\
\text { Before/ } \\
\text { CG }\end{array}$} & \multirow{2}{*}{$\begin{array}{l}\text { VM } \\
\text { Rate } \\
\text { After/ } \\
\text { IG }\end{array}$} \\
\hline & & & & $\begin{array}{l}\text { Antibiotic } \\
\text { Prophylaxis; } \\
\text { Patient Skin } \\
\text { Antisepsis }\end{array}$ & $\begin{array}{l}\text { Head Hair } \\
\text { Management }\end{array}$ & $\begin{array}{l}\text { SC } \\
\text { Tunneling; } \\
\text { Length }\end{array}$ & Other & $\begin{array}{l}\text { Aseptic } \\
\text { Management }\end{array}$ & $\begin{array}{l}\text { Dressing } \\
\text { Change; } \\
\text { Type }\end{array}$ & $\begin{array}{l}\text { CSF } \\
\text { Sampling } \\
\text { Frequency }\end{array}$ & Other & & & \\
\hline $\begin{array}{l}\text { Flint; 2013; } \\
\text { retrospective } \\
\text { before-after; } \\
2005-7 \text { and } \\
\text { 2009-1I; } \\
\text { USA; }{ }^{15}\end{array}$ & EVD & $\begin{array}{l}\text { Plain } \\
\text { (before), } \\
\text { AIC (after) }\end{array}$ & Yes;NS; yes & $\begin{array}{l}\text { Single dose } \\
\text { before; } \mathrm{CHX} \\
\text { antisepsis }\end{array}$ & Broad clipping & $3-5 \mathrm{~cm}$ & $\begin{array}{l}\text { ICU insertion; } \\
\text { all staff in room } \\
\text { wore mask and } \\
\text { cap; full draping } \\
\text { of patient's head } \\
\text { and body; }\end{array}$ & $\begin{array}{l}\text { Yes, strict } \\
\text { technique }\end{array}$ & $\begin{array}{l}\text { No routine } \\
\text { change; } \\
\text { adherent } \\
\text { transparent } \\
\text { dressing }\end{array}$ & $\begin{array}{l}\text { On clinical } \\
\text { indication }\end{array}$ & $\begin{array}{l}\text { Manipulation steps: a) all } \\
\text { staff in room wore mask } \\
\text { and cap; b) 3-way } \\
\text { stopcock positioned at } \\
45^{\circ} \text {, b) stopcock and } \\
\text { adjacent tubing } \\
\text { submerged into } \\
\text { isopropyl alcohol, c) the } \\
\text { physician wears sterile } \\
\text { gloves and gown, d) } \\
\text { rubbed with CHX, e) } \\
\text { port opened and cap } \\
\text { discarded, f) inner port } \\
\text { repeatedly rubbed with } \\
\text { CHX, g) saline rinsing, h) } \\
\text { CSF sampling or flush, i) } \\
\text { new, sterile cap placed }\end{array}$ & No; NS & $6.3 \%$ & $0.8 \% *$ \\
\hline $\begin{array}{l}\text { Kubilay; 2013; } \\
\text { prospective; } \\
\text { 2006-12; } \\
\text { USA; } 116\end{array}$ & EVD & AIC & $\begin{array}{l}\text { Yes; no; yes } \\
\text { (nurse } \\
\text { monitoring at } \\
\text { bedside) }\end{array}$ & $\begin{array}{l}\text { Before and up } \\
\text { to } 24 \text { hours; } \\
\text { iodine } \\
\text { povacrylex } \\
\text { and isopropyl } \\
\text { alcohol } \\
\text { antisepsis }\end{array}$ & Clipping & NS & $\begin{array}{l}\text { Compliance } \\
\text { monitoring by } \\
\text { the patient's } \\
\text { bedside nurse }\end{array}$ & Yes & NS & $\mathrm{N}$ & NA & NS & $9.2 \%$ & $0 \%$ \\
\hline
\end{tabular}




\begin{tabular}{|c|c|c|c|c|c|c|c|c|c|c|c|c|c|c|}
\hline $\begin{array}{l}\text { Lwin; 20I2; } \\
\text { Prospective, } \\
\text { 3-phased audit; } \\
\text { 2007-8; } \\
\text { Singapore; }{ }^{117}\end{array}$ & EVD & $\begin{array}{l}\text { Plain } \\
\text { initially and } \\
\text { SIC during } \\
\text { the last } \\
\text { phase }\end{array}$ & Yes; yes; yes & NS; NS & NS & NS & $\begin{array}{l}\text { Limiting the } \\
\text { number of } \\
\text { personnel in the } \\
\text { OR and } \\
\text { minimising the } \\
\text { duration of the } \\
\text { operation }\end{array}$ & Yes & NS & $\begin{array}{l}\text { When VM } \\
\text { was } \\
\text { suspected }\end{array}$ & - & $\begin{array}{l}\text { Within } 10 \text { days; } \\
\text { as soon as } \\
\text { possible }\end{array}$ & $6.1 \%$ & $0 \%$ \\
\hline $\begin{array}{l}\text { Kestle; 2011; } \\
\text { Prospective; } \\
\text { 2007-9; USA; }{ }^{18}\end{array}$ & $\begin{array}{l}\text { VPS, } \\
\text { VAS, } \\
\text { VPS }\end{array}$ & Non-AIC & Yes; yes; yes & $\begin{array}{l}\text { A dose before } \\
\text { and a second } \\
\text { dose following } \\
\text { operation; } \\
\mathrm{CHX} \\
\text { antisepsis }\end{array}$ & Clipping & $\begin{array}{l}\text { By } \\
\text { definition; } \\
\text { NA }\end{array}$ & $\begin{array}{l}\text { Limited traffic } \\
\text { in the OR; } \\
\text { Patient position } \\
\text { of the OR site } \\
\text { away from door }\end{array}$ & NS & NS & NA & - & NA & $8.8 \%$ & $5.7 \% *$ \\
\hline $\begin{array}{l}\text { Williams; 201 I; } \\
\text { before-after; } \\
\text { 2005-7; } \\
\text { Australia; }{ }^{19}\end{array}$ & EVD & NS & NS; NS; NS & $\begin{array}{l}\mathrm{NS} ; \mathrm{CHX} \\
\text { antisepsis }\end{array}$ & $\begin{array}{l}\text { Clipped or } \\
\text { shaved only } \\
\text { around bur } \\
\text { hole }\end{array}$ & No & - & Yes & $\begin{array}{l}\text { Every } 3 \text { days; } \\
\text { plain } \\
\text { transparent }\end{array}$ & $\begin{array}{l}\text { Daily vs } \\
\text { every } 3 \\
\text { days }\end{array}$ & $\begin{array}{l}\text { Unblocking by saline } \\
\text { with sterile gloves and } \\
\text { aseptic technique }\end{array}$ & NS & $17 \%$ & $10.8 \% *$ \\
\hline
\end{tabular}

Notes: *denotes significant reduction; ${ }^{\#}$ denotes nonsignificant VM reduction ; however, the bacterialregrowth at the catheter exit site was significantly decreased.

Abbreviations: AIC, antibiotic-impregnated catheter; CG, control group; CHX, chlorhexidine; CSF, cerebrospinal fluid; EVD, external ventricular drain; ICP, intracranial pressure; ICU, intensive care unit; IG, intervention group; IV, intravenous; IVT, intraventricular; NA, not applicable; NS, not specified; OR, operating room; SIC, silver-impregnated catheter; UK, United Kingdom; USA, United States of America; VAS, ventriculoatrial shunt; VP, ventriculoperitoneal shunt; $\mathrm{VPS}$, ventriculopleural shunt; $\mathrm{VM}$, ventriculitis or postoperative meningitis or healthcare-associated ventriculitis and meningitis. 
Table 3 Common Intraventricular/Intrathecal Treatment Options

\begin{tabular}{|c|c|c|c|c|}
\hline Drug & $\begin{array}{l}\text { Recommended } \\
\text { Adult Daily Dose }\end{array}$ & $\begin{array}{l}\text { Loading } \\
\text { Dose } \\
\text { Suggested }\end{array}$ & Adverse Events Reported ${ }^{136}$ & Targeted Pathogens $s^{2,136}$ \\
\hline Amikacin & $5-50 \mathrm{mg}$ & - & $\begin{array}{l}\text { Transient hearing loss, seizures, } \\
\text { chemical meningitis, radiculopathy (IT) }\end{array}$ & DTR Gram-negatives \\
\hline Colistin & $10 \mathrm{mg}$ & $40 \mathrm{mg}$ & Chemical meningitis, seizures & DTR Gram-negatives \\
\hline Daptomycin & $5 \mathrm{mg}$ & - & Limited data available & $\begin{array}{l}\text { Gram-positives non-responding to systemic } \\
\text { treatment }\end{array}$ \\
\hline Gentamycin & $4-8 \mathrm{mg}$ & - & Equivalent to amikacin & DTR Gram-negatives \\
\hline Polymyxin B & $5 \mathrm{mg}$ & - & Equivalent to colistin & DTR Gram-negatives \\
\hline Tigecycline ${ }^{* 176}$ & $4-8 m g$ & - & None attributed to the drug & $\begin{array}{l}\text { DTR Gram-negatives, especially if colistin- } \\
\text { resistant as well; potentially VRE }{ }^{177}\end{array}$ \\
\hline Tobramycin & $5-20 \mathrm{mg}$ & - & Equivalent to amikacin & DTR Gram-negatives \\
\hline Vancomycin & $5-20 \mathrm{mg}$ & - & CSF pleocytosis, headache & $\begin{array}{l}\text { Gram-positives non-responding to systemic } \\
\text { treatment }\end{array}$ \\
\hline
\end{tabular}

Notes: *Limited data available. ${ }^{\#}$ Apart from tigecycline, according to Infectious Disease Society of America recommendations. ${ }^{2}$

Abbreviations: CSF, cerebrospinal fluid; DTR, difficult-to-treat resistant; IT, intrathecal; VRE, vancomycin-resistant enterococci.

genes can identify the culprit pathogens faster. Better diagnostics should exclude AM and limit empirical treatment of VM (and, therefore, limit unnecessary resistant selection pressure).

Preemptive or earlier targeted treatment of the disease should commence instead, following the paradigm of Candida infections. Regarding IV antimicrobial chemotherapy, most available PK/PD studies are not robust enough to clearly define therapeutic targets. Meanwhile, CSF therapeutic drug monitoring is usually not available for many antibiotics in use for VM. The implementation of such monitoring will enable increasingly higher doses or more frequent dosing of IV antimicrobials with a broad therapeutic index, such as beta-lactam-antibiotics, to achieve therapeutic levels in the CSF.

The medical literature on intraventricular antibiotics has been fraught with case series and reports, and low-quality evidence. However, it describes the valuable experience to manage this demanding infection. Notably, IVT remains a last resort targeted therapy of VM due to DTR-GN isolates. The molecular identification of either a DTR-GN pathogen or a relevant resistance phenotype might expedite the initiation of this adjunct treatment to improve outcomes. Endoscopic treatment has recently supplemented antimicrobial chemotherapy; it comprises the evacuation of debris and ventricular lavage. Preliminary data on lavage preceding IVT colistin treatment demonstrated promising results for the treatment of VM due to multi-resistant $A$. baumannii and $K$. pneumoniae.

Regarding prevention, the use of bundles for infection prevention can be indispensable in the era of DTR bacteria and their corresponding "hard to handle" infections. Indeed, the Neurocritical society has recently published a set of suggested clinical performance measures which include a documented EVD insertion bundle. Novel antimicrobial combinations, active against Gram-negative pathogens and ventriculostomy catheters impregnated with these drugs, are needed.

To conclude, the recent advances in diagnosis, management, and prevention might help mitigate the devastating sequelae of this critical infection.

\section{Abbreviations}

AUC, area under the receiver operating curve; BCID, Biofire blood panel; CI, cell index; CNS, central nervous system; CSF, cerebrospinal fluid; DTR, difficult-to-treat resistant; EVD, external ventricular drain; GN, Gram-negative; GP, Gram-positive; IDSA, Infectious Diseases Society of America; IT, intrathecal; IVT, intraventricular; ME, meningitis/ 
encephalitis; MIC, minimal inhibitory concentration; NAAT, nucleic acid amplification test; PK, pharmacokinetics; PD, pharmacodynamics; RBC, red blood cell count; SAH, subarachnoid hemorrhage; VM, ventriculitis or postoperative meningitis or healthcare-associated ventriculitis and meningitis; VP, ventriculoperitoneal shunt; WBC, white blood cell count.

\section{Disclosure}

The authors declare no conflicts of interest in this work.

\section{References}

1. Hussein K, Bitterman R, Shofty B, Paul M, Neuberger A. Management of postneurosurgical meningitis: narrative review. Clin Microbiol Infect. 2017;23(9):621-628. doi:10.1016/j.cmi.2017.05.013

2. Tunkel AR, Hasbun R, Bhimrah A, et al. Infectious Disease Society of America's clinical practice guidelines for healthcare-associated ventriculitis and meningitis. Clin Infect Dis. 2017;64:e34-e65. doi:10.1093/cid/ciw861

3. McClelland S, Hall WA. Postoperative central nervous system infection: incidence and associated factors in 2111 neurosurgical procedures. Clin Infect Dis. 2007;45:55-59. doi:10.1086/518580

4. Chen C, Zhang B, Yu S, et al. The incidence and risk factors of meningitis after major craniotomy in China: a retrospective cohort study. PLoS One. 2014;9:e101961. doi:10.1371/journal.pone.0101961

5. Sader E, Moore J, Cervantes-Arslanian AM. Neurosurgical infections. Semin Neurol. 2019;39:507-514. doi:10.1055/s-0039-1693107

6. Ramanan M, Lipman J, Shorr A, Shankar A. A meta-analysis of ventriculostomy-associated cerebrospinal fluid infections. BMC Infect Dis. 2015;15:3. doi:10.1186/s12879-014-0712-z

7. Bischoff P, Schroder C, Gastmeier P, Geffers C. Surveillance of external ventricular drainage-associated meningitis and ventriculitis in German intensive care units. Infect Control Hosp Epidemiol. 2020;41(4):452-457. doi:10.1017/ice.2019.367

8. Simon TD, Hall M, Riva-Cambrin J, et al. Infection rates following initial cerebrospinal fluid shunt placement across pediatric hospitals in the United States. J Neurosurg Pediatr. 2009;4(2):156-165. doi:10.3171/2009.3.PEDS08215

9. Hasbun R. Central nervous system device infections. Curr Infect Dis Rep. 2016;18(11):34. doi:10.1007/s11908-016-0541-x

10. Bjerknes S, Skogsied IM, Saele T, Dietrichs E, Toft M. Surgical site infections after deep brain stimulation surgery: frequency, characteristics and management in a 10-year period. PLoS One. 2014;9(8):e105288. doi:10.1371/journal.pone.0105288

11. Schiess MC, Eldabe S, Konrad P, et al. Intrathecal baclofen for severe spasticity: longitudinal data from the product surveillance registry. Neuromodulation. 2020;23(7):996-1002. doi:10.1111/ner.13097

12. Adapa AR, Linzey JR, Moriguchi F, et al. Risk factors and morbidity associated with surgical site infection subtypes following adult neurosurgical procedures. Br J Neurosurg. 2021:1-7. doi:10.1080/02688697.2021.1905773

13. Li Z, Wu X, Yu J, et al. Empirical combination antibiotic therapy improves the outcome of nosocomial meningitis or ventriculitis in neuro-critical care patients. Surg Infect (Larchmt). 2016;17(4):465-472. doi:10.1089/sur.2015.060

14. Hersh EH, Yaeger KA, Neifert SN, Kim J, Dangayach NS, Weiss N. Patterns of health care costs due to external ventricular drain infections. World Neurosurg. 2019;128:e31-37. doi:10.1016/j.wneu.2019.03.197

15. Karvouniaris M, Brotis AG, Tsiamalou P, Fountas KN. The role of intraventricular antibiotics in the treatment of nosocomial ventriculitis/ meningitis from Gram-negative pathogens: a systematic review and meta-analysis. World Neurosurg. 2018;120:e637-e650. doi:10.1016/j. wneu.2018.08.138

16. Kadri S, Adjemian J, Lai YL, et al. Difficult-to-treat resistance in Gram-negative bacteremia at 173 US hospitals: retrospective cohort analysis of prevalence, predictors, and outcome of resistance to all first-line agents. Clin Infect Dis. 2018;67(12):1803-1814. doi:10.1093/cid/ ciy378

17. Cicek Senturk G, Ozay R, Kul G, et al. Evaluation of post-operative meningitis: comparison of meningitis caused by Acinetobacter spp. and other possible causes. Turk Neurosurg. 2019;29(6):804-810. doi:10.5137/1019-5149.JTN.25151-18.1

18. van de Beek D, Drake JM, Tunkel AR. Nosocomial Bacterial Meningitis. N Engl J Med. 2010;362(2):146-154. doi:10.1056/NEJMra0804573

19. Lozier AP, Sciacca RR, Romagnoli MF, Connolly ES Jr. Ventriculostomy-related infections: a critical review of the literature. Neurosurgery. 2002;51(1):170-181. doi:10.1097/00006123-200207000-00024

20. Zheng W-J, Li L-M, Hu Z-H, et al. Bilateral external ventricular drains increase ventriculostomy-associated cerebrospinal fluid infection in low modified graeb score intraventricular hemorrhage. World Neurosurg. 2018;116:e550-e555. doi:10.1016/j.wneu.2018.05.030

21. Simon TD, Butler J, Whitlock KB, et al. Risk factors for first cerebrospinal fluid shunt infection: findings from a multi-center prospective cohort study. J Pediatr. 2014;164(6):1462-1468. doi:10.1016/j.jpeds.2014.02.013

22. Conen A, Raabe A, Schaller K, Fux CA, Vajkoczy P, Trampuz A. Management of neurosurgical implant-associated infections. Swiss Med Wkly. 2020;150:w20208. doi:10.4414/smw.2020.20208

23. Mounier R, Lobo D, Cook F, et al. From the skin to the brain: pathophysiology of colonization and infection of external ventricular drain, a prospective observational study. PLoS One. 2015;10(11):e142320. doi:10.1371/journal.pone. 0142320

24. Ramirez P, Gordon M, Soriano A, et al. Assessment or the in vivo formation of biofilm on external ventricular drainages. Eur J Clin Microbiol Infect Dis. 2013;32:1437-1443. doi:10.1007/s10096-013-1895-8

25. Paharik AE, Horswill AR. The Staphylococcal Biofilm: adhesins, regulation, and host response. Microbiol Spectr. 2016;4(2). doi:10.1128/ microbiolspec.VMBF-0022-2015

26. Pompilio A, Scribano D, Sharsar M, Di Bonaventura G, Palamara AT, Ambrosi C. Gram-negative bacteria holding together in a biofilm: the Acinetobacter baumannii way. Microorganisms. 2021;9:1353. doi:10.3390/microorganisms9071353 
27. Citerio G, Signorini L, Bronco A, Vargiolu A, Rota M, Latronico N; on behalf of the Infezioni LIquoriali Catetere Correlate Study Investigators. External ventricular and lumbar drain device infections in ICU patients: a prospective multicenter Italian study. Crit Care Med. 2015;43:1630-1637. doi:10.1097/CCM.0000000000001019

28. Hussein K, Rabino G, Feder O, et al. Risk factors for meningitis in neurosurgical patients with cerebrospinal fluid drains: prospective observational cohort study. Acta Neurochir. 2019;161:517-524. doi:10.1007/s00701-019-03801-y

29. Munari M, Franzoi F, Sergi M, et al. Extensively drug-resistant and multidrug-resistant gram-negative pathogens in the neurocritical intensive care unit. Acta Neurochir. 2020. doi:10.1007/s00701-020-04611-3

30. Pandey S, Li L, Deng XY, Cui DM, Gao L. Outcome following the treatment of ventriculitis caused by multi/extensive drug resistance Gram negative Bacilli; Acinetobacter baumannii and Klebsiella pneumonia. Front Neurol. 2019;9:1174. doi:10.3389/fneur.2018.01174

31. Kurtaran B, Kuscu F, Ulu A, et al. The causes of postoperative meningitis: the comparison of Gram-negative and Gram-positive pathogens. Turk Neurosurg. 2018;28(4):589-596. doi:10.5137/1019-5149.JTN.20575-17.1

32. Rogers T, Sok K, Erickson T, et al. The comparison of Gram-positive and Gram-negative healthcare-associated ventriculitis and meningitis in adults and children. Intensive Care Med. 2020;46(1):128-131. doi:10.1007/s00134-019-05815-7

33. Chen M, Chen C, Yang Q, Zhan R. Candida meningitis in neurosurgical patients: a single-institute study of nine cases over 7 years. Epidemiol Infect. 2020;148:e148. doi:10.1017/S0950268820001144

34. O'Brien D, Stevens NT, Lim CH, et al. Candida infection of the central nervous system following neurosurgery: a 12-year review. Acta Neurochir. 2011;153:1347-1350. doi:10.1007/s00701-011-0990-9

35. Srihawan C, Lopez Castelblanco R, Salazar L, et al. Clinical characteristics and predictors of adverse outcome in adult and pediatric patients with healthcare-associated ventriculitis and meningitis. Open Forum Infect Dis. 2016;3(2):ofw077. doi:10.1093/ofid/ofw077

36. Rogers T, Sok K, Erickson T, et al. Impact of antibiotic therapy in the microbiological yield of healthcare-associated ventriculitis and meningitis. Open Forum Infect Dis. 2019;6(3):ofz050. doi:10.1093/ofid/ofz050

37. National Healthcare Safety Network [homepage on the Internet]. CDC/NHSN Surveillance Definitions for Specific Types of Infections 2021. Surveillance Definitions (cdc.gov); August 21, 2021.

38. Rabinstein AA, Sandhu K. Noninfectious fever in the NICU: incidence, causes and predictors. J Neurol Neurosurg Psychiatry. 2007;78 (11):1278-1280. doi:10.1136/jnnp.2006.112730

39. O'Horo J, Sampathkumar P. Infections in neurocritical care. Neurocrit Care. 2017;27(3):458-467. doi:10.1007/s12028-017-0420-9

40. Mounier R, Kapandji N, Birnbaum R, et al. Biofilm-associated infection: the hidden face of cerebrospinal fluid shunt malfunction. Acta Neurochir. 2016;158:2321-2324. doi:10.1007/s00701-016-2977-z

41. Martin RM, Zimmermann LL, Huynh M, et al. Diagnostic approach to health care- and device-associated central nervous system infections. $J$ Clin Microbiol. 2018;56(11):e00861-18.

42. Hasbun R. Healthcare-associated ventriculitis: current and emerging diagnostic and treatment strategies. Expert Rev Anti Infect Ther. 2021;19 (8):993-999. doi:10.1080/14787210.2021.1866544

43. Omar AS, El Shawarby A, Singh R. Early monitoring of ventriculostomy-related infections with procalcitonin in patients with ventricular drains. J Clin Monit Comput. 2015;29(6):759-765. doi:10.1007/s10877-015-9663-1

44. Zarrouk V, Vassor I, Bert F, et al. Evaluation of the management of postoperative aseptic meningitis. Clin Infect Dis. 2007;44:1555-1559. doi: $10.1086 / 518169$

45. Montes K, Jenkinson H, Habib OB, Esquenazi Y, Hasbun R. Corrected white blood cell count, cell index, and validation of a clinical model for the diagnosis of health care-associated ventriculitis and meningitis in adults with intracranial hemorrhage. Clin Neurol Neurosurg. 2019;178:36-41. doi:10.1016/j.clineuro.2019.01.012

46. Liew S, Richards S, Ho KM, Murray R. Utility of the cell index in predicting external ventricular drain-related ventriculo-meningitis. Neurocrit Care. 2020;33(3):776-784. doi:10.1007/s12028-020-00964-w

47. Sakushima K, Hayashino Y, Kawaguchi T, Jackson JL, Fukuhara S. Diagnostic accuracy of cerebrospinal fluid lactate for differentiating bacterial meningitis from aseptic meningitis: a meta-analysis. $J$ Infect. 2011;62:255-262. doi:10.1016/j.jinf.2011.02.010

48. Hill E, Bleck TP, Singh K, Ouyang B, Busl KM. CSF lactate is not a reliable indicator of bacterial ventriculitis in patients with ventriculostomies. Clin Neurol Neurosurg. 2017;157:95-98. doi:10.1016/j.clineuro.2017.03.021

49. Abudeev SA, Kiselev KV, Kruglyakov KM, et al. Cerebrospinal fluid presepsin as a marker of nosocomial infections of the central nervous system: a prospective observational study. Front Neurol. 2018;9:58. doi:10.3389/fneur.2018.00058

50. Zheng G, Zhang C, Zhang G, Shao C. Evaluation of the diagnostic and prognostic value of CSF presepsin levels in patients with postneurosurgical ventriculitis/meningitis. Infect Drug Resist. 2021;14:2901-2909. doi:10.2147/IDR.S325635

51. Lenski M, Biszok A, Neufischer K, Tonn J-C, Briegel J, Thon N. Significance of cerebrospinal fluid inflammatory markers for diagnosing external ventricular drain-associated ventriculitis in patients with severe traumatic brain injury. Neurosurg Focus. 2019;47(5):E15. doi:10.3171/ 2019.8.FOCUS19407

52. Lenski M, Huge V, Briegel J, Tonn J-C, Schichor C, Thon N. Interleukin-6 in the cerebrospinal fluid as biomarker for onset of vasospasm and ventriculitis after severe subarachnoidal hemorrhage. World Neurosurg. 2017;99:132-139. doi:10.1016/j.wneu.2016.11.131

53. Lenski M, Huge V, Schmutzer M, et al. Inflammatory markers in serum and cerebrospinal fluid for early detection of external ventricular drainassociated ventriculitis in patients with subarachnoid hemorrhage. J Neurosurg Anesthesiol. 2019;31(2):227-233. doi:10.1097/ ANA.0000000000000496

54. Zhang G, Yang C, Kang X, Gao Z, Wan H, Liu Y. The combination of cerebrospinal fluid procalcitonin, lactate, interleukin-8, and interleukin-10 levels for the diagnosis of post-neurosurgical bacterial meningitis: a prospective study. Ann Clin Biochem. 2019;56 (1):133-140. doi:10.1177/0004563218794729

55. Olguner SK, Boyar B, Alabaz D, et al. Tumor necrosis factor alpha and interleukin-1 beta levels in cerebrospinal fluid examination for the diagnosis of ventriculoperitoneal shunt-related ventriculitis. Childs Nerv Syst. 2019;35(4):629-636. doi:10.1007/s00381-019-04070-x

56. Liu Z-H, Tu P-H, Chen N-Y, et al. Raised proinflammatory cytokine production within cerebrospinal fluid precedes fever onset in patients with neurosurgery-associated bacterial meningitis. Crit Care Med. 2015;43(11):2416-2428. doi:10.1097/CCM.0000000000001188

57. Cuff SM, Merola JP, Twohig JP, Eberl M, Gray WP. Toll-like receptor linked cytokine profiles in cerebrospinal fluid discriminate neurological infection from sterile inflammation. Brain Commun. 2020;2(2):fcaa218. doi:10.1093/braincomms/fcaa218 
58. Piva S, Albani F, Fagoni N, et al. High-mobility group box-1 protein as a novel biomarker to diagnose healthcare-associated ventriculitis and meningitis: a pilot study. Minerva Anestesiol. 2021;87(1):43-51. doi:10.23736/S0375-9393.20.14222-6

59. Zheng G, Ji X, Yu X, et al. Development and verification of a discriminate algorithm for diagnosing post-neurosurgical bacterial meningitis-A multicenter observational study. J Clin Lab Anal. 2020;34(2):e23069. doi:10.1002/jcla.23069

60. Hernández Ortiz OH, García García HI, Muñoz Ramírez F, et al. Development of a prediction rule for diagnosing postoperative meningitis: a cross-sectional study. J Neurosurg. 2018;128:262-271. doi:10.3171/2016.10.JNS16379

61. Beaver M, Lagundzin D, Thapa I, et al. Cutibacterium acnes central nervous system catheter infection induces long-term changes in the cerebrospinal fluid proteome. Infect Immun. 2021;89(4). doi:10.1128/IAI.00531-20

62. Finger G, Worm PV, Dos Santos SC, Do Nascimento TL, Gallo P, Stefani MA. Cerebrospinal fluid collected by lumbar puncture has a higher diagnostic accuracy than collected by ventriculostomy. World Neurosurg. 2020;138:e683-e689. doi:10.1016/j.wneu.2020.03.045

63. Pittman ME, Thomas BS, Wallace MA, Weber CJ, Burnham CA. Routine testing for anaerobic bacteria in cerebrospinal fluid cultures improves recovery of clinically significant pathogens. J Clin Microbiol. 2014;52(6):1824-1829. doi:10.1128/JCM.00193-14

64. Desai A, Scott Lollis S, Missios S, et al. How long should cerebrospinal fluid cultures be held to detect shunt infections? J Neurosurg Pediatr. 2009;4(2):184-189. doi:10.3171/2009.4.PEDS08279

65. Gordon CL, Tokarz R, Briese T, et al. Evaluation of a multiplex polymerase chain reaction for early diagnosis of ventriculostomy-related infections. J Neurosurg. 2015;123(6):1586-1592. doi:10.3171/2014.11.JNS141036

66. Rath P-M, Schoch B, Adamzik M, Steinmann E, Buer J, Steinmann J. Value of multiplex PCR using cerebrospinal fluid for the diagnosis of ventriculostomy-related meningitis in neurosurgery patients. Infection. 2014;42(4):621-627. doi:10.1007/s15010-014-0590-8

67. Dąbrowski P, Jurkiewicz J, Czernicki Z, Koszewski W, Jasielski P. Polymerase chain reaction based detection of bacterial 16S rRNA gene in the cerebrospinal fluid in the diagnosis of bacterial central nervous system infection in the course of external cerebrospinal fluid drainage. Comparison with standard diagnostics currently used in clinical practice. Neurol Neurosurg Pol. 2017;51(5):388-394.

68. Banks JT, Bharara S, Tubbs RS, et al. Polymerase chain reaction for the rapid detection of cerebrospinal fluid shunt or ventriculostomy infections. Neurosurgery. 2005;57(6):1237-1243. doi:10.1227/01.NEU.0000186038.98817.72

69. Deutch S, Dahlberg D, Hedegaard J, Schmidt MB, Møller JK, Ostergaard L. Diagnosis of ventricular drainage-related bacterial meningitis by broad-range real-time polymerase chain reaction. Neurosurgery. 2007;61(2):306-311. doi:10.1227/01.NEU.0000255526.34956.E4

70. Perdigão Neto LV, Medeiros M, Ferreira SC, et al. Polymerase chain reaction targeting 16S ribosomal RNA for the diagnosis of bacterial meningitis after neurosurgery. Clinics (Sao Paulo). 2021;76:e2284. doi:10.6061/clinics/2021/e2284

71. Qian L, Shi Y, Li F, et al. Metagenomic next-generation sequencing of cerebrospinal fluid for the diagnosis of external ventricular and lumbar drainage-associated ventriculitis and meningitis. Front Microbiol. 2020;11:596175. doi:10.3389/fmicb.2020.596175

72. Biofire-diagnostics [homepage on the Internet]. Biofire FilmArray Meningitis/Encephalitis Panel (ME). BioFire Diagnostics (biofiredx.com); October 20, 2021.

73. Biofire-diagnostics [homepage on the Internet]. Biofire FilmArray Blood Culture Identification 2 Panel (BCID2). BioFire Blood Culture Identification (BCID) Panels | BioFire Diagnostics (biofiredx.com); October 20, 2021.

74. Lopez-Amor L, García-Prieto E, Fernandez-Suarez J, et al. Evaluation of a commercial multiplex PCR for diagnosis of central nervous system (CNS) nosocomial infections. J Microbiol Methods. 2020;171:105865. doi:10.1016/j.mimet.2020.105865

75. Zhang G, Zheng G, Zhang Y, Ma R, Kang X. Evaluation of a micro/nanofluidic chip platform for the high-throughput detection of bacteria and their antibiotic resistance genes in post-neurosurgical meningitis. Int J Infect Dis. 2018;70:115-120. doi:10.1016/j.ijid.2018.03.012

76. Bishop B, Geffen Y, Plaut A, et al. The use of matrix-assisted laser desorption/ionization time-of-flight mass spectrometry for rapid bacterial identification in patients with smear-positive bacterial meningitis. Clin Microbiol Infect. 2018;24:171-174. doi:10.1016/j.cmi.2017.05.014

77. Jost GF, Wasner M, Taub E, Walti L, Mariani L, Trampuz A. Sonication of catheter tips for improved detection of microorganisms on external ventricular drains and ventriculoperitoneal shunts. J Clin Neurosci. 2014;21:578-582. doi:10.1016/j.jocn.2013.05.025

78. Prinz V, Bayerl S, Renz N, Trampuz A, Vajkoczy P, Finger T. Sonication improves pathogen detection in ventriculoperitoneal shunt-associated infections. Neurosurgery. 2019;85:516-523. doi:10.1093/neuros/nyy383

79. Thomaidis PC, Pantazatou A, Kamariotis S, et al. sonication assisted microbiological diagnosis of implant-related infection caused by Prevotella disiens and Staphylococcus epidermidis in a patient with cranioplasty. BMC Res Notes. 2015;8:307. doi:10.1186/s13104-0151274-X

80. Apostolakis S. Use of focused ultrasound (sonication) for the diagnosis of infections in neurosurgical operations: a systematic review and meta-analysis. World Neurosurg. 2020;136:364-373.e2. doi:10.1016/j.wneu.2019.12.143

81. Lewis A, Wahlster S, Karinja S, Czeisler B, Kimberly T, Lord AS. Ventriculostomy-related infections (VRI): the performance of different definitions for diagnosing infection. Br J Neurosurg. 2016;30(1):49-56. doi:10.3109/02688697.2015.1080222

82. Mounier R, Lobo D, Cook F, et al. Clinical, biological, and microbiological pattern associated with ventriculostomy-related infection: a retrospective longitudinal study. Acta Neurochir. 2015;157(12):2209-2217. doi:10.1007/s00701-015-2574-6

83. Gozal YM, Farley CW, Hanseman DJ, et al. Ventriculostomy-associated infection: a new, standardized reporting definition and institutional experience. Neurocrit Care. 2014;21(1):147-151. doi:10.1007/s12028-013-9936-9

84. Honda H, Jones JC, Craighead MC, Diringer MN, Dacey RG, Warren DK. Reducing the incidence of intraventricular catheter-related ventriculitis in the neurology-neurosurgical intensive care unit at a tertiary care center in St Louis, Missouri: an 8-year follow-up study. Infect Control Hosp Epidemiol. 2010;31(10):1078-1081. doi:10.1086/656377

85. Mallucci CL, Jenkinson MD, Conroy EJ, et al.; BASICS Study collaborators. Antibiotic or silver versus standard ventriculoperitoneal shunts (BASICS): a multicentre, single-blinded, randomised trial and economic evaluation. Lancet. 2019;394(10208):1530-1539. doi:10.1016/S01406736(19)31603-4

86. Korinek AM, Reina M, Boch AL, Rivera AO, De Bels D, Puybasset L. Prevention of external ventricular drain-related ventriculitis. Acta Neurochir. 2005;147(1):39-45. doi:10.1007/s00701-004-0416-Z

87. Alleyne $\mathrm{CH}$ Jr, Hassan M, Zabramski JM. The efficacy and cost of prophylactic and perioprocedural antibiotics in patients with external ventricular drains. Neurosurgery. 2000;47(5):1124-1127. doi:10.1097/00006123-200011000-00020

88. Poon WS, Ng S, Wai S. CSF antibiotic prophylaxis for neurosurgical patients with ventriculostomy: a randomised study. Acta Neurochir Suppl. $1998 ; 71: 146-148$. 
89. Ratilal B, Costa J, Sampaio C. Antibiotic prophylaxis for surgical introduction of intracranial ventricular shunts. Cochrane Database Syst Rev. 2006;3:CD005365.

90. Fried HI, Nathan BR, Rowe AS, et al. The insertion and management of external ventricular drains: an evidence-based consensus statement. A statement for healthcare professionals from the neurocritical care society. Neurocrit Care. 2016;24(1):61-81. doi:10.1007/s12028-015-0224-8

91. Zabramski JM, Whiting D, Darouiche RO, et al. Efficacy of antimicrobial-impregnated external ventricular drain catheters: a prospective, randomized, controlled trial. J Neurosurg. 2003;98(4):725-730. doi:10.3171/jns.2003.98.4.0725

92. Parker SL, McGirt MJ, Murphy JA, Megerian JT, Stout M, Engelhart L. Comparative effectiveness of antibiotic-impregnated shunt catheters in the treatment of adult and pediatric hydrocephalus: analysis of 12,589 consecutive cases from 287 US hospital systems. J Neurosurg. 2015; 122 (2):443-448. doi:10.3171/2014.10.JNS13395

93. Wang X, Dong Y, Qi X-Q, Li Y-M, Huang C-G, Hou L-J. Clinical review: efficacy of antimicrobial impregnated catheters in external ventricular drainage - a systematic review and meta-analysis. Crit Care. 2013;17:234. doi:10.1186/cc12608

94. Atkinson RA, Fikrey L, Vail A, Patel HC. Silver-impregnated external-ventricular-drain-related cerebrospinal fluid infections: a meta-analysis. $J$ Hosp Infect. 2016;92(3):263-272. doi:10.1016/j.jhin.2015.09.014

95. Attenello FJ, Garces-Ambrossi GL, Zaidi HA, Sciubba DM, Jallo GI. Hospital costs associated with shunt infections in patients receiving antibiotic-impregnated shunt catheters versus standard shunt catheters. Neurosurgery. 2010;66(2):284-289. doi:10.1227/01. NEU.0000363405.12584.4D

96. Bayston R, Ashraf W, Pelegrin I, et al. An external ventricular drainage catheter impregnated with rifampicin, trimethoprim and triclosan, with extended activity against MDR Gram-negative bacteria: an in vitro and in vivo study. J Antimicrob Chemother. 2019;74:2959-2964. doi:10.1093/jac/dkz293

97. Holloway KL, Barnes T, Choi S, et al. Ventriculostomy infections: the effect of monitoring duration and catheter exchange in 584 patients. J Neurosurg. 1996;85(3):419-424. doi:10.3171/jns.1996.85.3.0419

98. Arabi Y, Memish ZA, Balkhy HH, et al. Ventriculostomy-associated infections: incidence and risk factors. Am J Infect Control. 2005;33 (3):137-143. doi:10.1016/j.ajic.2004.11.008

99. Mayhall CG, Archer NH, Lamb VA, et al. Ventriculostomy-related infections. A prospective epidemiologic study. $N$ Engl J Med. 1984;310 (9):553-559. doi:10.1056/NEJM198403013100903

100. Wong GK, Poon WS, Wai S, Yu LM, Lyon D, Lam JM. Failure of regular external ventricular drain exchange to reduce cerebrospinal fluid infection: result of a randomised controlled trial. J Neurol Neurosurg Psychiatry. 2002;73(6):759-761. doi:10.1136/jnnp.73.6.759

101. Chatzi M, Karvouniaris M, Makris D, et al. Bundle of measures for external cerebral ventricular drainage-associated ventriculitis. Crit Care Med. 2014;42(1):66-73. doi:10.1097/CCM.0b013e31829a70a5

102. Livesay S, Fried H, Gagnon D, et al. Clinical performance measures for neurocritical care: a statement for healthcare professionals from the neurocritical care society. Neurocrit Care. 2020;32(1):5-79. doi:10.1007/s12028-019-00846-w

103. Walek KW, Leary OP, Sastry R, Asaad WF, Walsh JM, Mermel L. Decreasing external ventricular drain infection rates in the neurocritical care unit: 12-year longitudinal experience at a single institution. World Neurosurg. 2021;150:e89-e101. doi:10.1016/j.wneu.2021.02.087

104. Thien A, Soh S, Lock C, et al. The National Neuroscience Institute External Ventricular Drain Study: a pragmatic multisite risk-stratification pathway to reduce ventriculostomy-related infection. World Neurosurg. 2020;135:e126-e136. doi:10.1016/j.wneu.2019.11.070

105. Yang LY, Wang R, Song P-X, et al. Impact of an educational program on reducing health care-associated meningitis or ventriculitis in the neurosurgical intensive care unit. Am J Infect Control. 2020;48(6):621-625. doi:10.1016/j.ajic.2019.10.012

106. Ates N, Kafadar A, Aygun G, Yildirim A. Usage of a bundle application process in decreasing ventriculoperitoneal shunt infections. Turk Neurosurg. 2020;30(4):550-556. doi:10.5137/1019-5149.JTN.26864-19.3

107. Whyte C, Alhasani H, Caplan R, Tully AP. Impact of an external ventricular drain bundle and limited duration antibiotic prophylaxis on drain-related infections and antibiotic resistance. Clin Neurol Neurosurg. 2020;190:105641. doi:10.1016/j.clineuro.2019.105641

108. Sweeney J, Zyck S, Tovar-Spinoza Z, Krishnamurthy S, Chin L, Bodman A. Evidence-based perioperative protocol for ventriculoperitoneal shunt infection reduction at a single institution. World Neurosurg. 2019;128:e814-e822. doi:10.1016/j.wneu.2019.04.261

109. Katzir M, Lefkowitz JJ, Ben-Reuven D, Fuchs SJ, Hussein K, Sviri GE. Decreasing external ventricular drain-related infection rates with duration-independent, clinically indicated criteria for drain revision: a retrospective study. World Neurosurg. 2019;131:e474-e481. doi:10.1016/ j.wneu.2019.07.205

110. Roethlisberger M, Moffa G, Fisch U, et al. Effectiveness of a chlorhexidine dressing on silver-coated. external ventricular drain-associated colonization and infection: a prospective single-blinded randomized controlled clinical trial. Clin Infect Dis. 2018;67(12):1868-1877. doi:10.1093/cid/ciy393

111. Omrani O, O'Connor J, Hartley J, James G. Effect of introduction of a standardised peri-operative protocol on CSF shunt infection rate: a single-centre cohort study of 809 procedures. Child Nerv Syst. 2018;34:2407-2414. doi:10.1007/s00381-018-3953-0

112. Ershova K, Savin I, Kurdyumova N, et al. Implementing an infection control and prevention program decreases the incidence of healthcare-associated infections and resistance in a Russian neuro-ICU. Antimicrob Resist Infect Control. 2018;7:94. doi:10.1186/s13756018-0383-4

113. Bashir A, Sørensen P. Evaluation of intraoperative glove change in prevention of postoperative cerebrospinal fluid shunt infections, and the predictors of shunt infection. Br J Neurosurg. 2017;31(4):452-458. doi:10.1080/02688697.2016.1229745

114. Camacho EF, Boszczowski I, Pinheiro Freire M, et al. Impact of an educational intervention implanted in a neurological intensive care unit on rates of infection related to external ventricular drains. PLoS One. 2013;8(2):e50708. doi:10.1371/journal.pone.0050708

115. Flint AC, Rao VA, Renda NC, Faigeles BS, Lasman TE, Sheridan W. A simple protocol to prevent external ventricular drain infections. Neurosurgery. 2013;72(6):993-999. doi:10.1227/NEU.0b013e31828e8dfd

116. Kubilay Z, Amini S, Fauerbach LL, Archibald L, Friedman WA, Layon AJ. Decreasing ventricular infections through the use of a ventriculostomy placement bundle: experience at a single institution. J Neurosurg. 2013;118(3):514-520. doi:10.3171/2012.11.JNS121336

117. Lwin S, Low SW, Seng Choy DK, Yeo TT, Chou N. External ventricular drain infections: successful implementation of strategies to reduce infection rate. Singapore Med J. 2012;53(4):255-259.

118. Kestle JRW, Riva-Cambrin J, Wellons JC III, et al. A standardized protocol to reduce cerebrospinal fluid shunt infection: the hydrocephalus clinical research network quality improvement initiative. J Neurosurg Pediatr. 2011;8(1):22-29. doi:10.3171/2011.4.PEDS10551 
119. Williams TA, Leslie GD, Dobb GJ, Roberts B, van Heerden PV. Decrease in proven ventriculitis by reducing the frequency of cerebrospinal fluid sampling from extraventricular drains. J Neurosurg. 2011;115(5):1040-1046. doi:10.3171/2011.6.JNS11167

120. Udy AA, Roberts JA, Shorr AF, Boots RJ, Lipman J. Augmented renal clearance in septic and traumatized patients with normal plasma creatinine concentrations: identifying at-risk patients. Crit Care. 2013;17(1):R35. doi:10.1186/cc12544

121. Abdul-Aziz MH, Alffenaar JWC, Bassetti M, et al.; Infection Section of European Society of Intensive Care Medicine (ESICM); Pharmacokinetic/pharmacodynamic and Critically Ill Patient Study Groups of European Society of Clinical Microbiology and Infectious Diseases (ESCMID); Infectious Diseases Group of International Association of Therapeutic Drug Monitoring and Clinical Toxicology (IATDMCT); Infections in the ICU and Sepsis Working Group of International Society of Antimicrobial Chemotherapy (ISAC). Antimicrobial therapeutic drug monitoring in critically ill adult patients: a Position Paper. Intensive Care Med. 2020;46(6):1127-1153. doi:10.1007/s00134-020-06050-1

122. Nau R, Sörgel F, Prange HW. Pharmacokinetic optimisation of the treatment of bacterial central nervous system infections. Clin Pharmacokinet. 1998;35(3):223-246. doi:10.2165/00003088-199835030-00005

123. Heffernan AJ, Roberts JA. Dose optimisation of antibiotics used for meningitis. Curr Opin Infect Dis. 2021;34(6):581-590. doi:10.1097/ QCO.0000000000000783

124. Lutsar I, McCracken GH Jr, Friedland IR. Antibiotic pharmacodynamics in cerebrospinal fluid. Clin Infect Dis. 1998;27(5):1117-1127. doi:10.1086/515003

125. Kumta N, Roberts JA, Lipman J, Cotta MO. Antibiotic distribution into cerebrospinal fluid: can dosing safely account for drug and disease factors in the treatment of ventriculostomy-associated infections? Clin Pharmacokinet. 2018;57(4):439-454. doi:10.1007/s40262-017-0588-3

126. Ziaka M, Markantonis SL, Fousteri M, et al. Combined intravenous and intraventricular administration of colistin methanesulfonate in critically ill patients with central nervous system infection. Antimicrob Agents Chemother. 2013;57:1938-1940. doi:10.1128/AAC.01461-12

127. Beach JE, Perrott J, Turgeon RD, Ensom MHH. Penetration of Vancomycin into the Cerebrospinal Fluid: a Systematic Review. Clin Pharmacokinet. 2017;56(12):1479-1490. doi:10.1007/s40262-017-0548-y

128. Nau R, Sörgel F, Eiffert H. Penetration of drugs through the blood-cerebrospinal fluid/blood-brain barrier for treatment of central nervous system infections. Clin Microbiol Rev. 2010;23(4):858-883. doi:10.1128/CMR.00007-10

129. Eliakim-Raz N, Lador A, Leibovici-Weissman Y, Elbaz M, Paul M, Leibovici L. Efficacy and safety of chloramphenicol: joining the revival of old antibiotics? Systematic review and meta-analysis of randomized controlled trials. J Antimicrob Chemother. 2015;70:979-996. doi:10.1093/jac/dku530

130. Pfausler B, Spiss H, Dittrich P, Zeitlinger M, Schmutzhard E, Joukhadar C. Concentrations of fosfomycin in the cerebrospinal fluid of neurointensive care patients with ventriculostomy associated ventriculitis. J Antimicrob Chemother. 2004;53:848-852. doi:10.1093/jac/dkh158

131. Tsegka KG, Voulgaris GL, Kyriakidou M, Falagas ME. Intravenous fosfomycin for the treatment of patients with central nervous system infections: evaluation of the published evidence. Expert Rev Anti Infect Ther. 2020;18(7):657-668. doi:10.1080/14787210.2020.1754193

132. van de Beek D, Cabellos C, Dzupova O, et al. ESCMID guideline: diagnosis and treatment of acute bacterial meningitis. Clin Microbiol Infect. 2016;22:S37-S62. doi:10.1016/j.cmi.2016.01.007

133. Piva S, Di Paolo A, Galeotti L, et al. Daptomycin plasma and CSF levels in patients with healthcare-associated meningitis. Neurocrit Care. 2019;31(1):116-124. doi:10.1007/s12028-018-0657-y

134. Chauzy A, Nadji A, Combes J-C, et al. Cerebrospinal fluid pharmacokinetics of ceftaroline in neurosurgical patients with an external ventricular drain. J Antimicrob Chemother. 2019;74:675-681. doi:10.1093/jac/dky489

135. Matzneller P, Burian A, Zeitlinger M, Sauermann R. Understanding the activity of antibiotics in cerebrospinal fluid in vitro. Pharmacology. 2016;97(5-6):233-244. doi:10.1159/000444263

136. Nau R, Blei C, Eiffert H. Intrathecal antibacterial and antifungal therapies. Clin Microbiol Rev. 2020;33(3):e00190-19. doi:10.1128/ CMR.00190-19

137. Hosmann A, Ritscher L, Burgmann H, et al. Meropenem concentrations in brain tissue of neurointensive care patients exceed CSF levels. $J$ Antimicrob Chemother. 2021;76(11):2914-2922. doi:10.1093/jac/dkab286

138. Zheng G, Cao Y, Liu C, et al. Phenotype, molecular characterisation and risk factors for postoperative meningitis caused by ESBL-producingEnterobacteriaceae: a six years multi-Centre comparative cohort study. BMC Infect Dis. 2021;21:85. doi:10.1186/s12879-021-05784-7

139. McCreary EK, Byers KE, Fernandes C, et al. Plasma and cerebrospinal fluid therapeutic drug monitoring of ceftolozane and tazobactam during treatment of multidrug-resistant Pseudomonas aeruginosa meningitis. Open Forum Infect Dis. 2020;7(12):ofaa549. doi:10.1093/ofid/ ofaa549

140. Winans SA, Guerrero-Wooley RL, Park SH, et al. Continuous infusion of ceftolozane-tazobactam resulted in high cerebrospinal fluid concentrations of ceftolozane in a patient with multidrug-resistant Pseudomonas aeruginosa meningitis. Infection. 2021;49(2):355-359. doi:10.1007/s15010-020-01510-8

141. Kerz T, Von loewenich FD, Roberts J, Neulen A, Ringel F. Cerebrospinal fluid penetration of very high-dose meropenem: a case report. Ann Clin Microbiol Antimicrob. 2018;17(1):47. doi:10.1186/s12941-018-0299-0

142. Roujansky A, Martin M, Gomart C, Hulin A, Mounier R. Multidrug-resistant Staphylococcus epidermidis ventriculostomy-related infection successfully treated by intravenous ceftaroline after failure of daptomycin treatment. World Neurosurg. 2020;136:221-225. doi:10.1016/j. wneu.2020.01.013

143. Chen HA, Yang CJ, Tsai MS, Liao CH, Lee CH. Linezolid as salvage therapy for central nervous system infections due to methicillin-resistant Staphylococcus aureus at two medical centers in Taiwan. J Microbiol Immunol Infect. 2020;53(6):909-915. doi:10.1016/j.jmii.2020.08.004

144. Pintado V, Pazos R, Jimenez-Mejias ME. Linezolid for therapy of Staphylococcus aureus meningitis: a cohort study of 26 patients. Infect Dis (Lond). 2020;52(11):808-815. doi:10.1080/23744235.2020.1789212

145. Mounier R, Lobo D, Hulin A, Nebbad B, Cook F, Dhonneur G. Is first line vancomycin still the best option to treat Staphylococcus healthcare-associated meningitis? World Neurosurg. 2017;9:812.e1-812.e5. doi:10.1016/j.wneu.2016.12.076

146. Tsuji BT, Pogue JM, Zavascki AP, et al. International Consensus Guidelines for the Optimal Use of the Polymyxins: endorsed by the American College of Clinical Pharmacy (ACCP), European Society of Clinical Microbiology and Infectious Diseases (ESCMID), Infectious Diseases Society of America (IDSA), International Society for Anti-infective Pharmacology (ISAP), Society of Critical Care Medicine (SCCM), and Society of Infectious Diseases Pharmacists (SIDP). Pharmacotherapy. 2019;39(1):10-39. doi:10.1002/phar.2209 
147. Paul M, Lador A, Grozinsky-Glasberg S, Leibovici L. Beta lactam antibiotic monotherapy versus beta lactam-aminoglycoside antibiotic combination therapy for sepsis. Cochrane Database Syst Rev. 2014;2014(1):CD003344.

148. Saelim W, Changpradub D, Thunyaharn S, Juntanawiwat P, Nulsopapon P, Santimaleeworagun W. Colistin plus sulbactam or fosfomycin against carbapenem-resistant Acinetobacter baumannii: improved efficacy or decreased risk of nephrotoxicity? Infect Chemother. 2021;53 (1):128-140. doi:10.3947/ic.2021.0007

149. Nwabor OF, Terbtothakun P, Voravuthikunchai SP, Chusri S. Evaluation of the synergistic antibacterial effects of fosfomycin in combination with selected antibiotics against carbapenem-resistant Acinetobacter baumannii. Pharmaceuticals (Basel). 2021;14(3):185. doi:10.3390/ ph14030185

150. Le Turnier P, Gregoire M, Deslandes G, et al.; NAMAP study group Nantes Anti-Microbial Agent Pk/PD. Should we reconsider cefazolin for treating staphylococcal meningitis? A retrospective analysis of cefazolin and cloxacillin CSF levels in patients treated for staphylococcal meningitis. Clin Microbiol Infect. 2020;26(10):1415.e1-1415.e4. doi:10.1016/j.cmi.2020.04.046

151. Roberts JA, Abdul-Aziz M-H, Davis JS, et al. Continuous versus intermittent b-Lactam infusion in severe sepsis. A meta-analysis of individual patient data from randomized trials. Am J Respir Crit Care Med. 2016;194(6):681-691. doi:10.1164/rccm.201601-00240C

152. Kondo Y, Ota K, Imura $\mathrm{H}$, et al. Prolonged versus intermittent $\beta$-lactam antibiotics intravenous infusion strategy in sepsis or septic shock patients: a systematic review with meta-analysis and trial sequential analysis of randomized trials. J Intensive Care. 2020;8:77. doi:10.1186/ s40560-020-00490-z

153. Blassmann U, Roehr AC, Frey OR, et al. Cerebrospinal fluid penetration of meropenem in neurocritical care patients with proven or suspected ventriculitis: a prospective observational study. Crit Care. 2016;20(1):343. doi:10.1186/s13054-016-1523-y

154. Grégoire M, Gaborit B, Deschanvres C, et al. High-dosage cefazolin achieves sufficient cerebrospinal diffusion to treat an external ventricular drainage-related Staphylococcus aureus ventriculitis. Antimicrob Agents Chemother. 2019;63(2):e01844-18. doi:10.1128/AAC.01844-18

155. Mader MM, Czorlich P, König C, et al. Intrathecal penetration of meropenem and vancomycin administered by continuous infusion in patients suffering from ventriculitis-a retrospective analysis. Acta Neurochir. 2018;160(11):2099-2105. doi:10.1007/s00701-018-3680-z

156. Blassmann U, Hope W, Roehr AC, et al. CSF penetration of vancomycin in critical care patients with proven or suspected ventriculitis: a prospective observational study. J Antimicrob Chemother. 2019;74:991-996. doi:10.1093/jac/dky543

157. Cawley MJ, Suh C, Lee S, Ackerman BH. Nontraditional dosing of ampicillin-sulbactam for multidrug-resistant Acinetobacter baumannii meningitis. Pharmacotherapy. 2002;22(4):527-532. doi:10.1592/phco.22.7.527.33676

158. Zhou Q, Wang H, Zhan T, Yang X, Wen L. Successful treatment of ventriculitis caused by MDR/XDR Gram-negative bacillus using ceftazidime/avibactam: case series and literature review. Infect Drug Resist. 2021;14:1691-1701. doi:10.2147/IDR.S306222

159. Kullar R, Chin JN, Edwards DJ, Parker D, Coplin WM, Rybak MJ. Pharmacokinetics of single-dose daptomycin in patients with suspected or confirmed neurological infections. Antimicrob Agents Chemother. 2011;55(7):3505-3509. doi:10.1128/AAC.01741-10

160. De Pascale G, Montini L, Pennisi MA, et al. High dose tigecycline in critically ill patients with severe infections due to multidrug-resistant bacteria. Crit Care. 2014;18:R90. doi:10.1186/cc13858

161. Khanum I, Ilyas A, Ali F. Stenotrophomonas maltophilia meningitis - a case series and review of the literature. Cureus. $2020 ; 12(10)$ :e11221. doi:10.7759/cureus.11221

162. Brown GR. Cotrimoxazole - optimal dosing in the critically ill. Ann Intensive Care. 2014;4:13. doi:10.1186/2110-5820-4-13

163. Falcone M, Daikos GL, Tiseo G, et al. Efficacy of ceftazidime-avibactam plus aztreonam in patients with bloodstream infections caused by MBL-producing Enterobacterobacterales. Clin Infect Dis. 2021;72(11):1871-1878. doi:10.1093/cid/ciaa586

164. Lee BJ, $\mathrm{Vu} \mathrm{BN}$, Seddon AN, Hodgson HA, Wang SA. Treatment considerations for CNS infections caused by vancomycin-resistant Enterococcus faecium: a focused review of linezolid and daptomycin. Ann Pharmacother. 2020;54(12):1243-1251. doi:10.1177/ 1060028020932513

165. Young EJ, Ratner RE, Clarridge JE. Staphylococcal ventriculitis treated with vancomycin. South Med J. 1981;74(8):1014-1015. doi:10.1097/ 00007611-198108000-00039

166. Kaiser AB, McGee ZA. Aminoglycoside therapy of gram-negative bacillary meningitis. N Engl J Med. 1975;293:1215-1220. doi:10.1056/ NEJM197512112932401

167. Remeš F, Tomáš R, Jindrák V, Vaniš V, Šetlík M. Intraventricular and lumbar intrathecal administration of antibiotics in postneurosurgical patients with meningitis and/or ventriculitis in a serious clinical state. J Neurosurg. 2013;119(6):1596-1602. doi:10.3171/2013.6.JNS122126

168. Wilkie MD, Hanson MF, Statham PF, Brennan PM. Infections of cerebrospinal fluid diversion devices in adults: the role of intraventricular antimicrobial therapy. $J$ Infect. 2013;66:239-246. doi:10.1016/j.jinf.2012.11.006

169. Bayston R, Hart CA, Barnicoat M. Intraventricular vancomycin in the treatment of ventriculitis associated with cerebrospinal fluid shunting and drainage. J Neurol Neurosurg Psychiatry. 1987;50(11):1419-1423. doi:10.1136/jnnp.50.11.1419

170. Denetclaw TH, Suehiro I, Wang PK, Tolliver GL. Successful treatment of ventriculostomy-associated meningitis caused by multidrug resistant coagulase-negative Staphylococcus epidermidis using low-volume intrathecal daptomycin and loading strategy. Ann Pharmacother. 2014;48 (10):1376-1379. doi:10.1177/1060028014542634

171. Tängdén T, Enblad P, Ullberg M, Sjölin J. Neurosurgical gram-negative bacillary ventriculitis and meningitis: a retrospective study evaluating the efficacy of intraventricular gentamicin therapy in 31 consecutive cases. Clin Infect Dis. 2011;52(11):1310-1316. doi:10.1093/cid/cir197

172. Wang $\mathrm{JH}$, Lin $\mathrm{PC}$, Chou $\mathrm{CH}$, et al. Intraventricular antimicrobial therapy in postneurosurgical gram-negative bacillary meningitis or ventriculitis: a hospital based retrospective study. J Microbiol Immunol Infect. 2014;47:204-210. doi:10.1016/j.jmii.2012.08.028

173. Karaiskos I, Galani L, Baziaka F, Giamarellou H. Intraventricular and intrathecal colistin as the last therapeutic resort for the treatment of multidrug resistant and extensively drug-resistant Acinetobacter baumannii ventriculitis and meningitis: a literature review. Int $J$ Antimicrob Agents. 2013;41:499-508. doi:10.1016/j.ijantimicag.2013.02.006

174. European Medicines Agency completes review of polymyxin-based medicines [homepage on the Internet]. Recommendations issued for safe use in patients with serious infections resistant to standard antibiotics. European Medicines Agency completes review of polymyxin-based medicines | European Medicines Agency (europa.eu); October 10, 2021.

175. Pan S, Huang X, Wang Y, et al. Efficacy of intravenous plus intrathecal/intracerebral ventricle injection of polymyxin B for post-neurosurgical intracranial infections due to MDR/XDR Acinectobacter baumannii: a retrospective cohort study. Antimicrob Resist Infect Control. $2018 ; 7: 8$. doi:10.1186/s13756-018-0305-5 
176. Tsolaki V, Karvouniaris M, Manoulakas E, et al. Intraventricular CNS treatment with Colistin-Tigecycline combination: a case series. $J$ Crit Care. 2018;47:338-341. doi:10.1016/j.jcrc.2018.07.025

177. Şahin A, Dalgic N. Intraventricular plus intravenous tigecycline for the treatment of daptomycin nonsusceptible vancomycin-resistant enterococci in an infant with ventriculoperitoneal shunt infection. World Neurosurg. 2019;130:470-473. doi:10.1016/j.wneu.2019.07.045

178. Imberti R, Cusato M, Accetta G, et al. Pharmacokinetics of colistin in cerebrospinal fluid after intraventricular administration of colistin methanesulfonate. Antimicrob Agents Chemother. 2012;56(8):4416-4421. doi:10.1128/AAC.00231-12

179. LeBras M, Chow I, Mabasa VH, Ensom MH. Systematic review of efficacy, pharmacokinetics, and administration of intraventricular aminoglycosides in adults. Neurocrit Care. 2016;25:492-507. doi:10.1007/s12028-016-0269-3

180. Karaiskos I, Galani L, Baziaka F, et al. Successful treatment of extensively drug-resistant Acinetobacter baumannii ventriculitis and meningitis with intraventricular colistin after application of a loading dose: a case series. Int J Antimicrob Agents. 2013;41(6):480-483. doi:10.1016/j. ijantimicag.2013.02.010

181. Lewin JJ III, Cook AM, Gonzales C, et al. Current practices of intraventricular antibiotic therapy in the treatment of meningitis and ventriculitis: results from a multicenter retrospective cohort study. Neurocrit Care. 2019;30(3):609-616. doi:10.1007/s12028-018-0647-0

182. Brotis AG, Churis I, Karvouniaris M. Local complications of adjunct intrathecal antibiotics for nosocomial meningitis associated with gram-negative pathogens: a meta-analysis. Neurosurg Rev. 2021;44(1):139-152. doi:10.1007/s10143-019-01226-w

183. Lang M, Habboub G, Moore NZ, et al. Neuroendoscopic evacuation of intraventricular empyema using a side-cutting aspiration device. $J$ Clin Neurosci. 2018;47:323-327. doi:10.1016/j.jocn.2017.09.029

184. Qin G, Liang Y, Xu K, et al. Neuroendoscopic lavage for ventriculitis: case report and literature review. Neurochirurgie. 2020;66:127-132. doi:10.1016/j.neuchi.2019.12.005

185. Wang F, Yao X-Y, Zou Z-R, Yu H-L, Sun T. Management of pyogenic cerebral ventriculitis by neuroendoscopic surgery. World Neurosurg. 2017;98:6-13. doi:10.1016/j.wneu.2016.10.103

186. Yuen J, Chen B, Brent A, Plaha P. Endoscopic washout for medically refractory cerebral ventriculitis. J Neurosurg Sci. $2018 ; 62(4): 523-526$. doi:10.23736/S0390-5616.17.03967-4

187. Chen F, Deng X, Wang Z, Wang L, Wang K, Gao L. Treatment of severe ventriculitis caused by extensively drug resistant Acinetobacter baumannii by intraventricular lavage and administration of colistin. Infect Drug Resist. 2019;12:241-247. doi:10.2147/IDR.S186646

188. Sharma R, Goda R, Borkar SA, et al. Outcome following postneurosurgical Acinetobacter meningitis: an institutional experience of 72 cases. Neurosurg Focus. 2019;47(2):E8. doi:10.3171/2019.5.FOCUS19278

189. Shi Y, Zheng G, Qian L, Qsman RA, Li G, Zhang G. Longitudinal analysis of risk factors for clinical outcomes of Enterobacteriaceae meningitis/encephalitis in post-neurosurgical patients: a comparative cohort study during 2014-2019. Infect Drug Resist. 2020;13:2161-2170. doi:10.2147/IDR.S252331

190. Ceylan B, Arslan F, Sipahi OR, et al. Variables determining mortality in patients with Acinetobacter baumannii meningitis/ventriculitis treated with intrathecal colistin. Clin Neurol Neurosurg. 2017;153:43-49. doi:10.1016/j.clineuro.2016.12.006

191. Murthy SB, Moradiya Y, Shah J, Hanley DF, Ziai WC. Incidence, predictors, and outcomes of ventriculostomy-associated infections in spontaneous intracerebral hemorrhage. Neurocrit Care. 2016;24(3):389-396. doi:10.1007/s12028-015-0199-5

192. Habib OB, Srihawan C, Salazar L, Hasbun R. Prognostic impact of healthcare-associated meningitis in adults with intracranial hemorrhage. World Neurosurg. 2017;107:772-777. doi:10.1016/j.wneu.2017.08.118

\section{Publish your work in this journal}

Infection and Drug Resistance is an international, peer-reviewed open-access journal that focuses on the optimal treatment of infection (bacterial, fungal and viral) and the development and institution of preventive strategies to minimize the development and spread of resistance. The journal is specifically concerned with the epidemiology of antibiotic resistance and the mechanisms of resistance development and diffusion in both hospitals and the community. The manuscript management system is completely online and includes a very quick and fair peer-review system, which is all easy to use. Visit http://www.dovepress.com/testimonials.php to read real quotes from published authors.

Submit your manuscript here: https://www.dovepress.com/infection-and-drug-resistance-journal 